\title{
Effect of Topographic Position and Seasons on the Micronutrient Levels in Soils and Grown Huckleberry (Solanum scabrum) in Bafut (North-West Cameroon)
}

\author{
P. Azinwi Tamfuh ${ }^{1}$, D. Tsozué, ${ }^{2, *}$, M.A. Tita ${ }^{3}$, A. Boukong ${ }^{1}$, R. Ngnipa Tchinda ${ }^{1}$, \\ H. Ntangmo Tsafack ${ }^{4}$, A.D. Mvondo Ze ${ }^{1}$
}

\begin{abstract}
${ }^{1}$ Department of Soil Science, Faculty of Agronomy and Agricultural Sciences, University of Dschang, P.O. Box 222, Dschang, Cameroon ${ }^{2}$ Department of Earth Sciences, Faculty of Sciences, University of Maroua, P.O. Box 814, Maroua, Cameroon ${ }^{3}$ Department of Biology, Higher Teacher Training College, Bambili, University of Bamenda, P.O. Box 39, Bambili, Cameroon ${ }^{4}$ Department of Animal Biology, Faculty of Sciences, University of Dschang, P.O. Box 67, Dschang, Cameroon *Corresponding author: tsozudsir@yahoo.f
\end{abstract}

\begin{abstract}
Although topography and climate are known to affect soil micronutrient mobility, some related aspects like micronutrient bioavailability to plants and implications to human intake are not fully understood. This paper aimed to study the effects of different topographic positions and seasons (dry or humid) on micronutrient levels in soils and Solanum scabrum. A randomized complete block design with four replications was adopted for each topographic position. Fieldwork was completed by a battery of soil and vegetable analyses. The main results revealed that soil micronutrient levels appeared as follows: $\mathrm{Al}>\mathrm{Fe}>\mathrm{Mn}>\mathrm{Zn}>\mathrm{Cu}$ for all positions and seasons. The soil micronutrient levels were lowest for the midslope in relation to its steeper gradient that affects downwards migration of matter. $\mathrm{Zn}$ and $\mathrm{Cu}$ were below the recommended range for agricultural soils, while $\mathrm{Al}$ was far above in relation to the strongly acidic $\mathrm{pH}$. In $\mathrm{S}$. scabrum, micronutrients appeared as $\mathrm{Mn}>\mathrm{Fe}>\mathrm{Zn}>\mathrm{Al}>\mathrm{Cu}$. Globally, vegetable metal levels were higher in the dry season for all positions. Except Al, all metals were below permissible and toxicity levels in food, while only Fe, $\mathrm{Mn}$ and $\mathrm{Zn}$ where above recommended range for normal plant growth. Metal transfer factors, apart from midslope, were higher in the dry season. Only Mn and $\mathrm{Zn}$ for all positions and seasons as well as $\mathrm{Zn}$ at footslope, were above 1. Globally, micronutrient levels in soils and vegetables were higher in the dry seasons for all positions. Micronutrient intake rates were higher in the dry season for all positions but lowest in the midslope for all seasons. Except Fe and $\mathrm{Zn}$ in adults, metal levels were above the recommended daily dietary intake indicating excess micronutrients intake by the inhabitants. Overall, a combination of steep slope and humid season reduces soil micronutrient level, limit uptake by vegetables and hence reduce mean daily intake in humans.
\end{abstract}

Keywords: Soil catena, Solanum scabrum, micronutrients, bioavailability, transfer factors, daily intake

Cite This Article: P. Azinwi Tamfuh, D. Tsozué, M.A. Tita, A. Boukong, R. Ngnipa Tchinda, H. Ntangmo Tsafack, and A.D. Mvondo Ze, "Effect of Topographic Position and Seasons on the Micronutrient Levels in Soils and Grown Huckleberry (Solanum scabrum) in Bafut (North-West Cameroon)." World Journal of Agricultural Research, vol. 5, no. 2 (2017): 73-87. doi: 10.12691/wjar-5-2-3.

\section{Introduction}

Topography and climate are two important factors influencing soil properties at regional scale due to their role in weathering and lateral migration of matter $[1,2,3,4]$. Movement of matter plays a vital role in soil nutrient status, plant nutrient uptake and crop performance $[5,6]$. One of the causative factors of nutritional deficiency of crops is poor soil fertility [7,8]. Plants obtain their nutrients directly from the soil substratum on which they grow $[2,4]$. Soil-plant nutrient interaction is thus vital for plant performance and has a direct bearing on effects related to deficiency and toxicity to plants as well as secondary consumers including humans [9,10,11]. Micronutrients are essential plant nutrients, although needed by plants in minute quantities without which they may not be able to complete their life cycles $[12,13,14,15,16]$. Through their involvement in various enzymes and other physiologically active molecules, these micronutrients are important for gene expression, biosynthesis of proteins, nucleic acids, growth substances, chlorophyll and secondary metabolites, metabolism of carbohydrates and lipids, stress tolerance etc $[17,18]$. $S$. scabrum is one of the most cultivated vegetables in Cameroon, especially in the Cameroon Western Highlands $[19,20]$. Considerable interest has been manifested in the cultivation of huckleberry to combat the ever increasing hunger and micronutrient deficiencies especially in children and expectant mothers from the developing countries [19,21-25]. It is one of vegetables that easily absorbs micronutrients from the soil and easily accumulates them in edible parts (leaves and stems) often 
to toxic levels $[16,26,27,28]$. These vegetables are cultivated in several locations in the humid Cameroon Western highlands at different topographic posisions and at different seasons [19,25,30]. Much works have been reported on the micronutrient contents of soils [31-36], as well as heavy metal contents of S. scabrum [8,21-26]. However, works that describe the distribution of micronutrients in soils and supported $S$. scabrum at various topographic positions and at different seasons are rare. The lack of attention is due to a number of constraints including the need for multiplicity of experimental points and at different seasons, the time required for land preparation, planting, sampling and analysis, the high number of samples and a wide battery of laboratory analyses that prevent many investigators from conducting such studies in most developing countries. The objective of this work was to assess the surface soil general characteristics, levels of some micronutrient in soils and grown $S$. scabrum along a soil catena and to estimate the mean human daily intake of micronutrients. The results obtained will supplement the available data on the micronutrients levels of soils and bioavailability in vegetables commonly consumed in Cameroon and beyond.

\section{Materials and methods}

\subsection{Study area}

Bafut Sub-division is located in the north of Mezam Division (North West Region of Cameroon) between latitude $06^{\circ} 05^{\prime}-06^{\circ} 11^{\prime} \mathrm{N}$ and longitude $09^{\circ} 58^{\prime}-10^{\circ} 11^{\prime} \mathrm{E}$ (Figure 1) [37]. It is situated at about $20 \mathrm{~km}$ northwest of Bamenda and covers a surface area of $340 \mathrm{Km}^{2}$. The mean annual precipitation is $2657.2 \mathrm{~mm}$, with a long rainy season from March to November and a dry one from December to February. The mean annual temperature is $22.3^{\circ} \mathrm{C}$ [38]. The natural vegetation of Bafut is the grassland savannah, marked by grasses mixed with deciduous shrubs and stunted trees here and there, meanwhile the swampy valleys are dominated by raffia bushes and palm trees [39]. This natural vegetation is strongly modified by human activities mainly farming and demographic pressure imposed by a rapidly increasing population [40]. On a hydrographic point of view, Bafut Sub-division is drained by River Mezam (main collector) and its tributaries [41]. The drainage system forms a sparse and more or less angular drainage pattern [42]. Geologically, Bafut sub-division is located along the Cameroon Volcanic Line and comprises three main geological formations: volcanic rocks, metamorphic rocks and alluvial deposits [43]. The metamorphic rocks, mainly gneiss and schist, outcrop mainly in the North especially on slopes of high plateaus and constitute the basement. The volcanic rocks, mostly basalts, outcrop in south Bafut. The alluvial deposits cover the Mezam River valley. The distribution of soils in Bafut is conditioned chiefly by topography and climate. Thus, ferrallitic soils occur in the southern high plateaus. In the north, most of the hill slopes are covered by brunified soils; alluvial soils are abundant in the Mezam river valley. Hydromorphic soils are common in the swampy valleys [44]. The estimated population of 80305 inhabitants (2005 census) is settled in three main zones: the Mumala'a (heart of the country) at the Centre clustered around the Fon's palace, the Ntare (ridge area) to the South and the Mbunti (lower) to the North which descends abruptly to the Menchum valley. In Bafut Sub-division, vegetable cultivation is all year round to ensure a continuous supply, but cultivation is intensified in the dry season when it is more lucrative. In the rainy season, vegetable is grown both in uplands and lowlands. In the dry seasons, it is cultivated only in lowlands close to the banks of the Mezam River, main water course which runs through the Bafut municipality and whose water serves for irrigation. Hand watering with cans is common but flood irrigation is more common in the valleys. Most of the farmers usually have a home garden for home consumption and a garden for commercial purposes usually some distance away from the home. A topographic survey of the study area was carried out and the study area (interfluve) was divided into three topographic positions (upslope, midslope and footslope) across three neighborhoods (Mambu, Manka'a and Bujong, respectively) following a NE-SW transect (Figure 2).

\subsection{Methodology}

\subsubsection{Experimental Design and Land Preparation}

The studied topographic positions were upslope, midslope and footslope (Figure 2). A randomized complete block design with four replications was adopted for each position. For each position, the experimental procedure was done in the rainy season and dry season making a total number of 24 studied experimental units.

The soil was cultivated using a digging fork to improve water infiltration. All plant residues were removed during cultivation and irrigation was done to improve soil moisture before planting.

\subsubsection{Planting and Management}

The $S$. scabrum seeds were purchased in the Bafut Main Market at 150 FCFA (about \$ 0.3) per glass and planted in mid-March 2015 (rainy season) and in December 2015 (dry season). Experimental units were watered where after there was need to keep the soil moist throughout the study. Weeds were removed by uprooting each time they appeared in the experimental units for the entire duration of the study. No fertilizer was applied throughout the growing period.

\subsubsection{Sample Collection and Pre-treatment}

The vegetable shoots were harvested at six weeks after planting. Thus, the stems were randomly cut at about 15 $\mathrm{cm}$ from the soil surface within each demarcated $5 \mathrm{~m}$ by 5 $\mathrm{m}$ sub-plot using a ceramic scissors to form a final composite sample of about $1 \mathrm{~kg}$. All together, four composite vegetable samples were obtained per $10 \mathrm{~m}$ x 10 $\mathrm{m}$ plot making a total number of 24 samples.

In each sub-plot, before transplantation, four soil samples were randomly collected at 0-20 cm depth (rooting zone) using a plastic shovel to avoid any metal contamination. These samples were mixed together to obtain a composite sample per sub-plot, thus making four composite soil samples per plot per season. All together, 
24 composite soil samples were obtained. Samples were stored in clean plastic bags immediately after collection and conveyed to the laboratory for further description and analysis. In the laboratory, the soil samples were air-dried at room temperature for one week and passed through a 2-mm polyethylene sieve to remove plant debris and pebbles. Afterwards, they were lightly crushed in an agate mortar into fine powder and passed through a $0.149-\mathrm{mm}$ nylon sieve. The vegetable samples were washed three times with distilled water to remove soil particles and were then oven-dried at $75^{\circ} \mathrm{C}$ to a constant weight for 48 hours. The dried vegetable samples were crushed into fine powder in an agate mortar and passed through a $0.149-\mathrm{mm}$ nylon sieve. The soil and vegetable powders were then stored in glass containers and preserved under ambient conditions pending analysis.

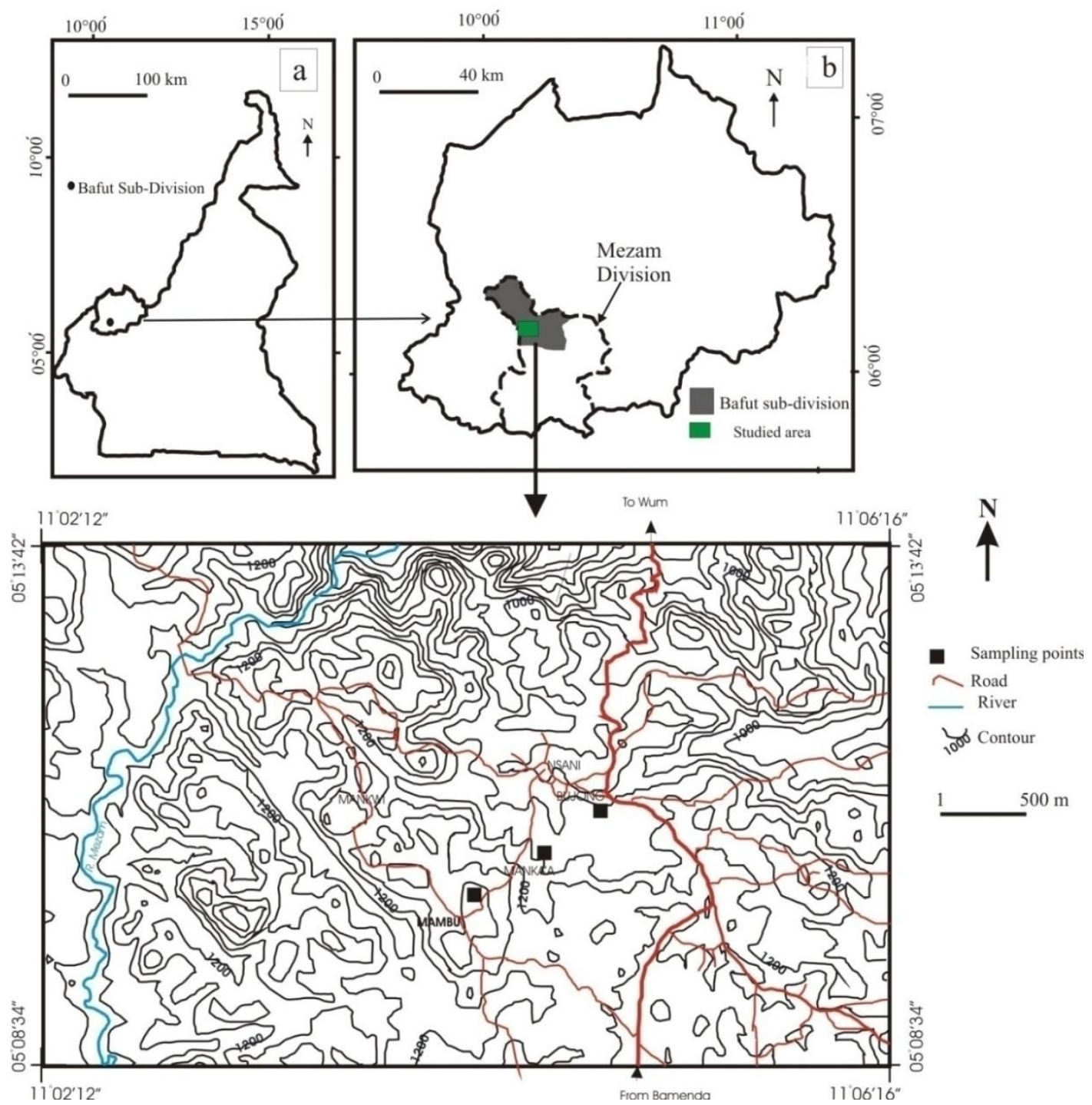

Figure 1. Relief and location of studied area

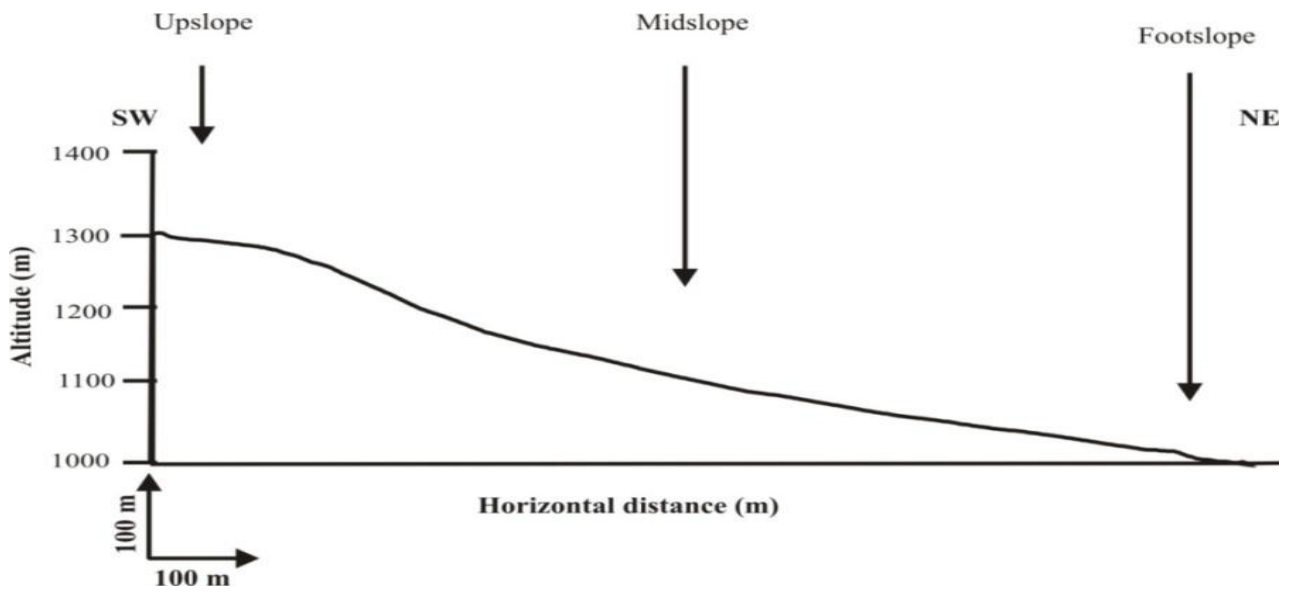

Figure 2. Topographic cross section along the studied transect 


\subsubsection{Laboratory Analyses of Soils and Vegetables}

The soil physico-chemical analyses and micronutrient analyses of soils and vegetables were done at the Soil Science Laboratory of the Faculty of Agronomy and Agricultural Sciences (FASA) of the University of Dschang (Cameroon). The soil relative humidity was determined by noting the weight-loss of an air-dried sample, after subjecting it to an oven temperature of $105^{\circ} \mathrm{C}$ for 24 hours [45]. The bulk density was determined in reference to Archimedes' principle and particle density was measured by pycnometer method [45]. Soil porosity was deduced from bulk density and particle density [45]. The particle size distribution was measured by Robinson's pipette method [45]. The $\mathrm{pH}-\mathrm{H}_{2} \mathrm{O}$ was determined in a soil/water ratio of 1:2.5 and the $\mathrm{pH} \mathrm{KCl}$ was determined in a soil/ $\mathrm{KCl}$ composition of 1:2.5 [46]. The organic carbon (OC) was measured by Walkley-Black method [47]. Organic matter $(\mathrm{OM})$ was obtained from organic carbon (OC) using the Sprengel factor as in equation (1) [47].

$$
\mathrm{OM}=\mathrm{OC} \times 1.724 \text {. }
$$

Total nitrogen (TN) was measured by the Kjeldahl method [48]. Available phosphorus was determined by concentrated nitric acid reduction method [49]. Exchangeable cations were analyzed by ammonium acetate extraction at $\mathrm{pH} 7$ [50]. The cation exchange capacity was measured by sodium saturation method [51]. The base saturation was calculated as the percentage of the sum of exchangeable cations $(S)$ divided by the cations exchange capacity (CEC). The exchangeable aluminum was extracted in a $1 \mathrm{M} \mathrm{KCl}$ solution and evaluated by colourimetry with the violet pyrocathecol method [52]. Structural stability index and slaking index were calculated according to [54] and [55], respectively. Aluminum toxicity was defined by the Kamprath method [53] as in equation (2).

$$
\mathrm{m}=\frac{\mathrm{Al}}{\mathrm{Al}+\mathrm{S}} \mathrm{X} 100 .
$$

Soil micronutrient levels were measured by total digestion method [56]. Thus, aliquots of $0.5 \mathrm{~g}$ of dried soil samples were digested with $\mathrm{HNO}_{3}$ acid, $\mathrm{H}_{2} \mathrm{O}_{2}$ and $\mathrm{HCl}$ acid mixture in the ratio $5: 1: 1$ at $80^{\circ} \mathrm{C}$ until a clear solution was obtained. The solution was filtered through Whatman no. 42 filter paper and diluted to $50 \mathrm{ml}$ with deionized water. The filtrates were then directly analyzed for $\mathrm{Fe}, \mathrm{Mn}, \mathrm{Cu}$ and $\mathrm{Zn}$ using atomic absorption spectrophotometry PG-900 Model, equipped with an airacetylene flame and a hollow cathode lamp, under standard conditions using wavelengths and slit-widths specified for each element [57].

The dried vegetable samples were digested with $\mathrm{HNO}_{3}$ acid, $\mathrm{H}_{2} \mathrm{O}_{2}$ and $\mathrm{HCl}$ acid mixture in a 5:1:1 ratio, filtered, diluted to $50 \mathrm{ml}$ and then analyzed for $\mathrm{Fe}, \mathrm{Mn}, \mathrm{Cu}$ and $\mathrm{Zn}$ by Atomic Absorption Spectrophotometry PG-900 Model [57]. All soil and vegetable samples were analyzed along with a blank solution. Calibration was performed with standard solutions while precision and accuracy where checked by repeated analyses of sub-samples of standards. Soil and vegetable micronutrient concentrations were expressed in $\mathrm{mg} \mathrm{kg}^{-1}$. The metal transfer factors were calculated as the concentration of the metal in the vegetable relative to contents in soil before planting [58].
The daily intake ( $\mathrm{mg} \mathrm{kg}^{-1} \mathrm{day}^{-1}$ ) of each micronutrient, based on data from the Bafut District Hospital in 2015 and the results of a current vegetable consumption survey in the study area (Azinwi Tamfuh $\mathrm{P}$, in preparation), was calculated from the adult mean weight $(61 \mathrm{~kg})$, adult's daily vegetable intake (26 g), children's mean weight (12 $\mathrm{kg}$ ) and children vegetable daily intake (18 g) based on the equation (3) according to [16]:

$$
\begin{aligned}
& \text { Daily intake }\left(\mathrm{mg} \mathrm{kg}^{-1}\right) \\
& =\text { Mean micronutrient conc.in vegetable } \\
& \mathrm{X} \frac{\text { Vegetable weight }}{\text { Body weight }} .
\end{aligned}
$$

\subsubsection{Statistical Analysis}

Statistical analysis was performed using the SPSS software program (SPSS Inc., Version 12.0). The data were analyzed by one-way analysis of variance (ANOVA). The Tukey's test was used to detect the statistical significance of differences $(P<0.05)$ between means.

\section{Results}

\subsection{Soil Physico-chemical Characteristics}

The soil physico-chemical characteristics are presented in Table 1. The soils showed a high bulk density and low porosity. The texture ranged from sandy clay at the upslope to clayey at the midslope and heavy clayey texture at the footslope. The silt/clay ratios of the upslope and footslope positions varied from 0.28 to 0.62 , while the midslope had a silt/clay ratio of 0.93 for RMS and 0.77 for DMS (Table 1). The soil pH was very acidic. The organic matter content was average at the upslope and midslope but very high in the footslope. The exchangeable cations were as follows: $\mathrm{Ca}$ was low to very low, $\mathrm{Mg}$ was low, $\mathrm{K}$ was low to very low and $\mathrm{Na}$ was very low. The sum of exchangeable bases was low at the upslope and midslope but moderate at the footslope. The CEC was low for all the studied positions and seasons. The available phosphorus was also moderate for all the positions and seasons. The Al toxicity of these soils was moderate for all the positions and seasons, although slightly higher at the footslope.

\subsection{Distribution and Levels of micronutrients in Soils along the Catena}

The mean $\mathrm{Fe}$ contents of the soils ranged between 36 and $128 \mathrm{mg} \mathrm{kg}^{-1}$ for all the topographic positions and seasons (Figure 3). Between topographic positions, all soil $\mathrm{Fe}$ contents showed significant differences $\quad(P<0.05$. Between seasons, there was a significant difference $(P<0.05)$ between all treatments.

The mean Mn contents of the soils were very high for all topographic positions and seasons, ranging between (27 and $103 \mathrm{mg} \mathrm{kg}^{-1}$ ) (Figure 3). Apart from the DFS and RMS, based on topography, all the Mn contents showed no significant difference $(P<0.05)$. Between seasons, only DFS and RMS were significantly different from the rest of the treatments $(P<0.05)$. 
Table 1. Soil characteristics (0-20 cm depth) along the soil catena in Bafut sub-division

\begin{tabular}{|c|c|c|c|c|c|c|c|}
\hline \multirow{2}{*}{\multicolumn{2}{|c|}{ Soil properties }} & \multicolumn{2}{|c|}{ Footslope } & \multicolumn{2}{|c|}{ Midslope } & \multicolumn{2}{|c|}{ Upslope } \\
\hline & & RFS & DFS & RMS & DMS & RUS & DUS \\
\hline \multicolumn{2}{|c|}{ Moisture content $\left(105^{\circ} \mathrm{C}\right)$} & 16.3 & 15.80 & 15.2 & 8.20 & 14.3 & 7.12 \\
\hline \multicolumn{2}{|c|}{ Particle density $\left(\mathrm{g} \mathrm{cm}^{-3}\right)$} & 2.6 & 2.6 & 2.6 & 2.6 & 2.6 & 2.6 \\
\hline \multicolumn{2}{|c|}{ Bulk density $\left(\mathrm{g} \mathrm{cm}^{-3}\right)$} & 1.7 & 1.7 & 1.5 & 1.5 & 1.5 & 1.5 \\
\hline \multicolumn{2}{|l|}{ Porosity $(\%)$} & 34.6 & 34.6 & 42.3 & 42.3 & 42.3 & 42.3 \\
\hline \multirow{4}{*}{ Texture } & Sand & 32 & 26 & 21 & 23 & 51 & 55 \\
\hline & Silt & 16 & 20 & 38 & 34 & 17 & 10 \\
\hline & Clay & 52 & 54 & 41 & 43 & 32 & 35 \\
\hline & Textural class & Heavy clay & Heavy clay & Clay & Clay & Sandy clay & Sandy clay \\
\hline \multicolumn{2}{|l|}{$\mathrm{pH}\left(\mathrm{H}_{2} \mathrm{O}\right)$} & 4.3 & 4.6 & 4.2 & 4.4 & 4.9 & 4.6 \\
\hline \multicolumn{2}{|l|}{$\mathrm{pH}(\mathrm{KCl})$} & 4.0 & 4.4 & 4.9 & 4.3 & 4.7 & 4.4 \\
\hline \multicolumn{2}{|l|}{$\Delta \mathrm{pH}$} & 0.3 & 0.2 & 0.3 & 0.1 & 0.2 & 0.2 \\
\hline \multicolumn{2}{|l|}{ Organic carbon $(\%)$} & 4.8 & 5.1 & 2.8 & 3.7 & 4.06 & 3.9 \\
\hline \multicolumn{2}{|l|}{ Organic matter $(\%)$} & 8.3 & 8.9 & 4.9 & 6.36 & 7.07 & 6.79 \\
\hline \multicolumn{2}{|l|}{ Total nitrogen $(\%)$} & 0.42 & 0.56 & 0.16 & 0.08 & 0.11 & 0.07 \\
\hline \multirow{4}{*}{$\begin{array}{l}\text { Exchangeable bases } \\
\left(\mathrm{cmol}+\mathrm{kg}^{-1}\right)\end{array}$} & $\mathrm{Ca}^{2+}$ & 3.4 & 3.6 & 1.6 & 1.9 & 1.46 & 1.6 \\
\hline & $\mathrm{Mg}^{2+}$ & 1.3 & 1.5 & 0.98 & 1.12 & 1.2 & 1.40 \\
\hline & $\mathrm{K}^{+}$ & 0.38 & 0.29 & 0.15 & 0.16 & 0.11 & 0.2 \\
\hline & $\mathrm{Na}^{+}$ & 0.11 & 0.10 & - & - & 0.05 & 0.08 \\
\hline \multicolumn{2}{|c|}{ Sum of exchangeable bases $\left(\mathrm{cmol}+\mathrm{kg}^{-1}\right)$} & 5.19 & 5.49 & 2.73 & 3.18 & 3.42 & 3.55 \\
\hline \multicolumn{2}{|c|}{$\mathrm{CEC}\left(\mathrm{cmol}+\mathrm{kg}^{-1}\right)$} & 17.9 & 18.6 & 12.2 & 12.5 & 10.5 & 11.01 \\
\hline \multicolumn{2}{|c|}{ Available phosphorus (ppm) } & 30.9 & 27.06 & 17.22 & 22.1 & 24.8 & 34.1 \\
\hline \multicolumn{2}{|c|}{ Exchangeable $\mathrm{Al}\left(\mathrm{cmol}+\mathrm{kg}^{-1}\right)$} & 1.85 & 1.59 & 0.99 & 0.56 & 0.92 & 0.77 \\
\hline \multicolumn{2}{|c|}{$\mathrm{Al}$ toxicity $(\%)$} & 35.65 & 28.96 & 36.26 & 17.61 & 26.90 & 21.69 \\
\hline \multicolumn{2}{|l|}{$\mathrm{C} / \mathrm{N}$ ratio } & 11.43 & 9.11 & 17.50 & 46.25 & 36.91 & 55.71 \\
\hline \multicolumn{2}{|l|}{$\mathrm{Ca} / \mathrm{Mg}$ ratio } & $2.6^{\mathrm{a}, 1}$ & $2.4^{\mathrm{a}, 1}$ & $1.6^{\mathrm{a}, 1}$ & $1.6^{\mathrm{a}, 1}$ & $1.2^{\mathrm{a}, 1}$ & $1.1^{\mathrm{a}, 1}$ \\
\hline \multicolumn{2}{|l|}{$\mathrm{Mg} / \mathrm{K}$ ratio } & $3.4^{\mathrm{a}, 1}$ & $5.2^{\mathrm{a}, 1}$ & $6.5^{\mathrm{a}, 1}$ & $7.0^{\mathrm{b}, 1}$ & $10.9^{\mathrm{b}, 1}$ & $7.0^{\mathrm{b}, 1}$ \\
\hline \multicolumn{2}{|c|}{ Exchangeable sodium \% (ESP) } & $0.61^{\mathrm{a}, 1}$ & $0.54^{\mathrm{a}, 1}$ & - & - & $0.47^{\mathrm{a}, 1}$ & $0.72^{\mathrm{a}, 1}$ \\
\hline \multicolumn{2}{|c|}{ S/CEC $(\%)$} & $28.9^{\mathrm{a}, 1}$ & $29.5^{\mathrm{a}, 1}$ & $22.62^{a, 1}$ & $25.35^{\text {a, } 1}$ & $32.57^{\mathrm{a}, 1}$ & $32.24^{\mathrm{a}, 1}$ \\
\hline \multicolumn{2}{|l|}{$\mathrm{Ca} / \mathrm{Mg} / \mathrm{K}$ ratio } & 66.9:25.6:7.5 & 66.8:27.8:5.4 & 58.6:35.9:5.5 & 59.8:35.2:5.0 & 52.7:43.3:4.0 & 50.0:43.8:6.3 \\
\hline \multicolumn{2}{|c|}{ CEC/Clay ratio } & 0.34 & 0.34 & 0.30 & 0.28 & 0.33 & 0.31 \\
\hline Structural stability in & & 12.2 & 12.0 & 7.9 & 9.1 & 14.4 & 15.1 \\
\hline Slaking index & & 0.68 & 0.64 & 0.65 & 0.55 & 0.42 & 0.21 \\
\hline
\end{tabular}

RFS: Rainy season footslope soils; DFS: Dry season footslope soils; RMS: rainy season midslope soils; DMS: dry season midslope soils; RUS: rainy season upslope soils; DUS: dry season upslope soils.

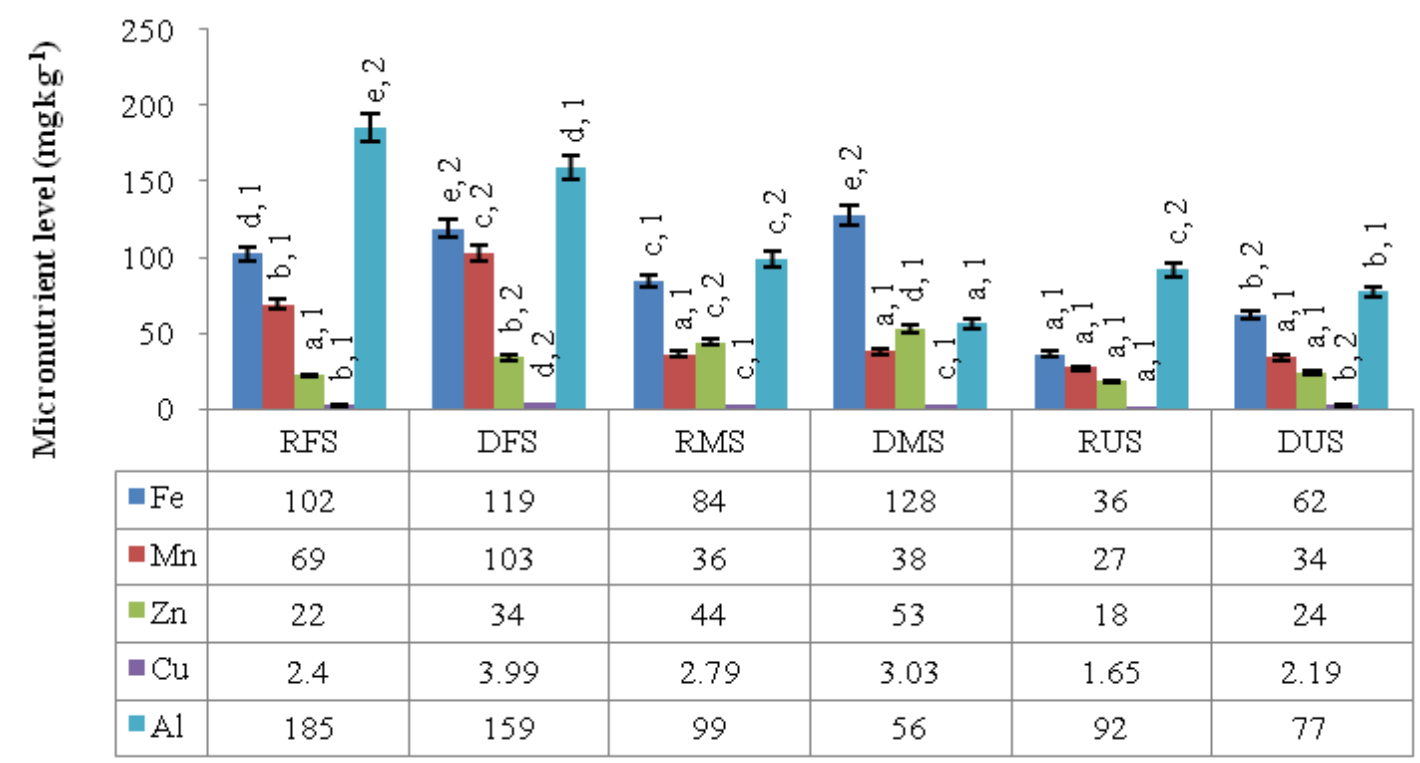

Soil sample

Figure 3. Mean micronutrient composition of soils along the catena (RFS: Rainy season footslope soils; DFS: Dry season footslope soils; RMS: rainy season midslope soils; DMS: dry season midslope soils; RUS: rainy season upslope soils; DUS: dry season upslope soils). Between topographic positions, bars with same shades, followed by different letters are significantly different at $\mathrm{P}<0.05$; within topographic position, bars with the same shade followed by different numbers are significantly different at $\mathrm{p}<0.05$ for different seasons) 
The $\mathrm{Zn}$ concentrations of the soils were very high for all the studied topographic and seasons (Figure 2). Between positions, RFS, RUS and DUS were significantly different from the rest of the treatments. Between seasons, only RUS and DUS did not show any significant difference in $\mathrm{Zn}$ concentrations.

The $\mathrm{Cu}$ contents of the studied soils were moderate for upland in rainy season to very high for the rest of the studied sites and seasons (Table 2; Figure 3). Between position, there was a significant difference $(P<0.05)$ between the $\mathrm{Cu}$ contents of the different landscape positions, apart from midslope. Between seasons, only the midslope soils did not show any variations in $\mathrm{Cu}$ contents with seasons.

The $\mathrm{Al}$ contents of the studied soils ranged from 56 to $185 \mathrm{mg} \mathrm{kg}^{-1}$ (Table 2; Figure 3). The highest values were noted at the footslope, but decreased significantly at the midslope and upslope. Between positions, there was a significant difference in soil $\mathrm{Al}$ concentrations between all the topographic positions and seasons.

The mean Fe/Mn ratios were high for DMS and RMS (midslope), while the rest were low, except DUS which was moderate (Figure 4). RMS and DMS were significant different in $\mathrm{Fe} / \mathrm{Mn}$ compared to the other positions.

\subsection{Micronutrient Composition of S. scabrum Samples along the Catena}

The micronutrient levels of the studied S. scabrum appeared as $\mathrm{Mn}>\mathrm{Fe}>\mathrm{Zn}>\mathrm{Cu}$ (Figure 5).

$\mathrm{Mn}$ was the most concentrated micronutrient in the S. scabrum and ranged between 53 and $178.6 \mathrm{mg} \mathrm{kg}^{-1}$ (Figure 5). The highest contents were observed for DMV and the lowest ones were shown by the RUV. Apart from RFV and RMV, the rest of the Mn contents did not vary significantly between topographic positions. Between seasons, the Mn contents were significantly different $(P<0.05)$ for all the topographic positions.

The $\mathrm{Zn}$ contents of the $S$. scabrum ranged between 6.06 and $44.3 \mathrm{mg} \mathrm{kg}^{-1}$ (Figure 5). The highest $\mathrm{Zn}$ contents were observed for RFV and the lowest ones were shown by RUV. Apart from RUV and RMV, there was no significant difference $(P<0.05)$ in $\mathrm{Zn}$ contents between the $S$. scabrum for the rest of the topographic positions. Between seasons, all the topographic positions showed a significant difference between seasons.

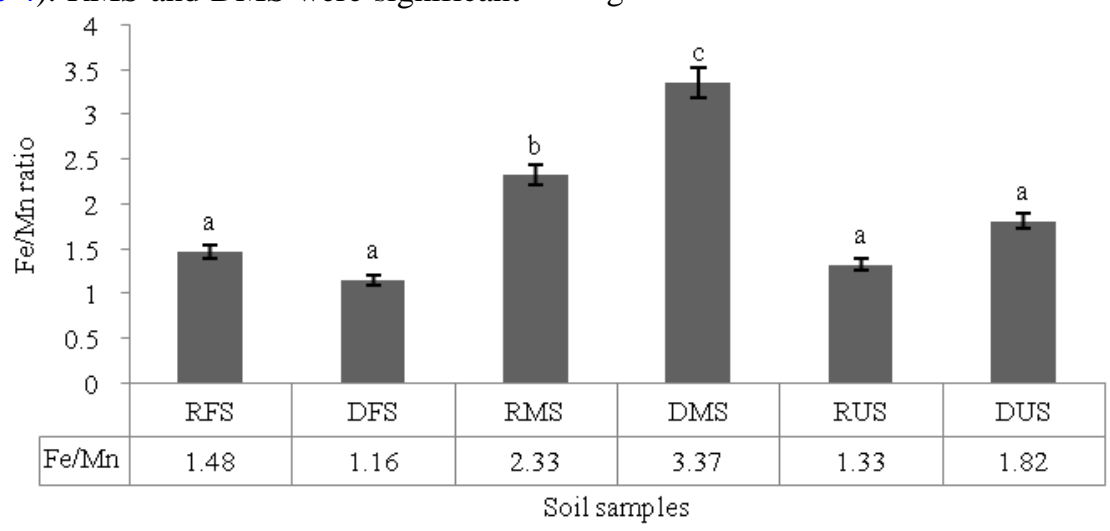

Figure 4. Fe/Mn ratio for the different soil samples. Bars with different letters are significantly different at $\mathrm{p}<0.05$ for different seasons

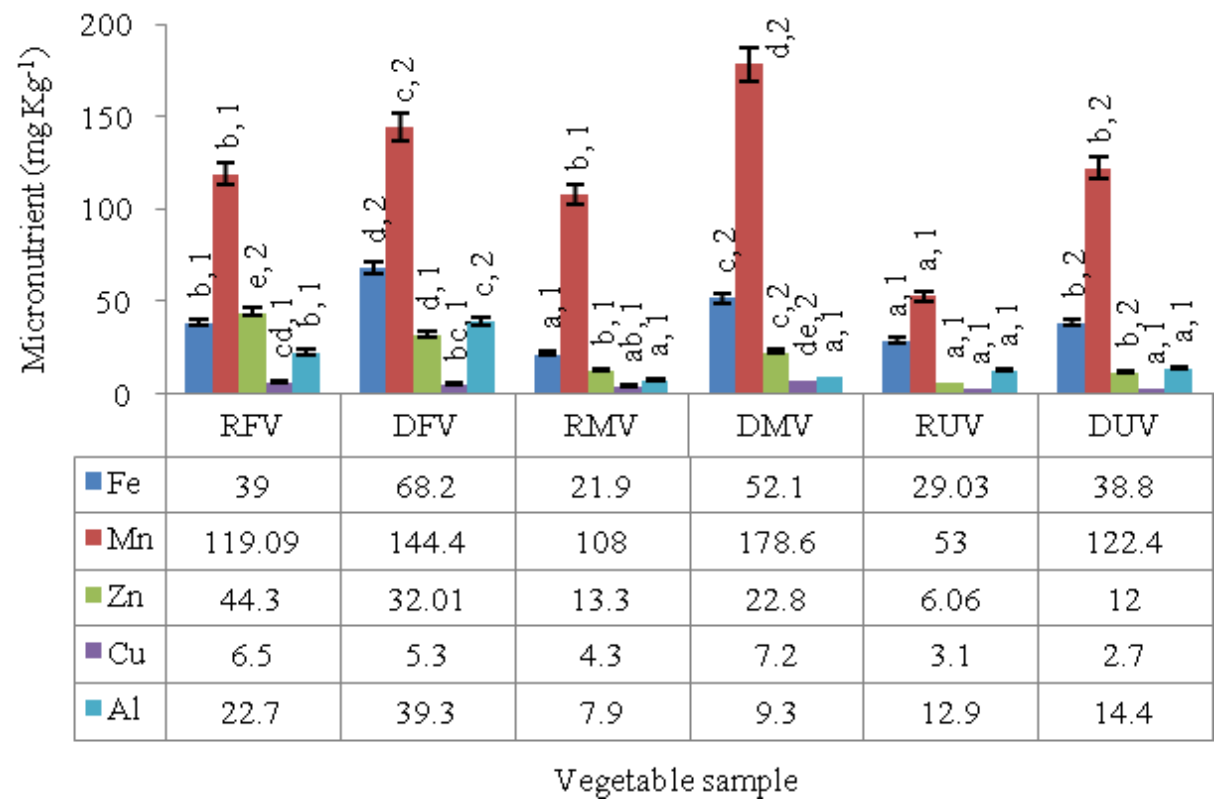

Figure 5. Micronutrient composition of S. scabrum along the catena (RFV: Rainy season footslope vegetables; DFV: Dry season footslope vegetables; RMV: rainy season midslope vegetables; DMV: dry season midslope vegetables; RUV: rainy season upslope vegetables; DUV: dry season upslope vegetables; between topographic positions, bars with same shades, followed by different letters are significantly different at $\mathrm{P}<0.05$; within topographic positions (between seasons), bars with the same shade followed by different numbers are significantly different at $\mathrm{p}<0.05$ for different seasons) 
The Fe contents in S. scabrum ranged from 21.9 to $68.2 \mathrm{mg} \mathrm{kg}^{-1}$ (Figure 5). The highest Fe contents were observed for DFV and the lowest ones were shown by the RMV. There was a significant difference $(P<0.05)$ in $\mathrm{Fe}$ contents for all the topographic positions. Season-wise, there is a significant difference $(P<0.05)$ in Fe contents for all seasons.

The $\mathrm{Cu}$ contents in the $S$. scabrum ranged between 2.7 and $7.2 \mathrm{mg} \mathrm{kg}^{-1}$ (Figure 5). The highest values were observed for DMV while the lowest ones were noted for DUV. However, the upslope vegetables showed lower $\mathrm{Cu}$ contents compared to those of the footslope. Apart from upslope, There was a significant difference $(P<0.05)$ in $\mathrm{Cu}$ contents between all the seasons.

The mean $\mathrm{Al}$ contents of the vegetables ranged from 7.9 to $39.3 \mathrm{mg} \mathrm{kg}^{-1}$ (Figure 5). The highest $\mathrm{Al}$ values were found in DFV while the lowest ones were recorded in RMV. Amongst topographic positions, there was a significant difference in Al concentration between RMV and RUV and the rest of the landscape positions. Among seasons, only footslope vegetables showed a significant difference between seasons $(P<0.05)$.

\subsection{Soil-plant Metal Transfer Factors (TF)}

Soil-plant metal transfer factors were high (>1) for Mn and $\mathrm{Cu}$, but low for $\mathrm{Zn}, \mathrm{Fe}$ and $\mathrm{Al}(<1)$ (Figure 6).

The TF of Mn globally ranged between 1.4 and 4.7. The highest TF values were recorded for the midslope (4.7 for the dry season and 3.0 for the rainy season), while the lowest values where observed in the dry season at upslope and footslope. Based on position, the upslope showed a significant difference in TF values for Fe meanwhile there was no significant difference between seasons. For $\mathrm{Mn}$, only the midslope vegetables were significantly different from the other positions and between seasons. The TF of $\mathrm{Cu}$ ranged between 1.23 and 2.71. Only the dry season footslope, rainy season midslope values were not significantly different from the rest of the TF for the different positions. Meanwhile, a significant difference $(P<0.05)$ was observed between $\mathrm{Cu} \mathrm{TF}$ of at midslope for the rainy and the dry season. The iron $\mathrm{TF}$ showed no significant difference between positions and seasons. The $\mathrm{TF}$ of $\mathrm{Zn}$ showed the same trend as $\mathrm{Fe}$ except for footslope at rainy season, which is high (2.01) and also significantly different from all other TF values. The TF values of $\mathrm{Al}$ were the lowest of all the micronutrients. Apart from rainy season midslope, there was no significant difference in $\mathrm{Al} \mathrm{TF}$ values between positions and seasons.

\subsection{Linear Correlations (r)}

Most of the vegetable micronutrients were correlated, either negatively or positively, with the soils physicochemical characteristics and micronutrients (Table 2). Nevertheless, it was observed that $\mathrm{Al}$ and clay were positively correlated with most of the other soil metals, while $\mathrm{pH}\left(\mathrm{H}_{2} \mathrm{O}\right)$ and organic matter were negatively correlated with most of the soil characteristics and micronutrients. Except for DFS, there was a strong positive correlation $(p<0.01)$ between $\mathrm{Fe}$ and $\mathrm{Al}$ in the soil as well as with most of the other metals especially at mid-slope and footslope. The rest of the metals showed strong correlations mainly at footslope and midslope. Many redundancies were however observed implying that similar variables showed positive correlations in one topographic position and seasons and negative correlations in the next position.

$\mathrm{Mn}, \mathrm{Zn}$ and $\mathrm{Cu}$ correlated positively with most of the other metals between plants and soils (Table 3). Al showed strong and weak negative correlations with most of the other metals but for all Mn (except RUS). Soil and plant iron were negatively correlated for almost all position, except RMS. Soil Al was negatively correlated with plant $\mathrm{Al}$. $\mathrm{Mn}$ versus $\mathrm{Mn}, \mathrm{Zn}$ versus $\mathrm{Zn}$ and $\mathrm{Cu}$ versus copper were positively correlated for most of the positions and seasons.

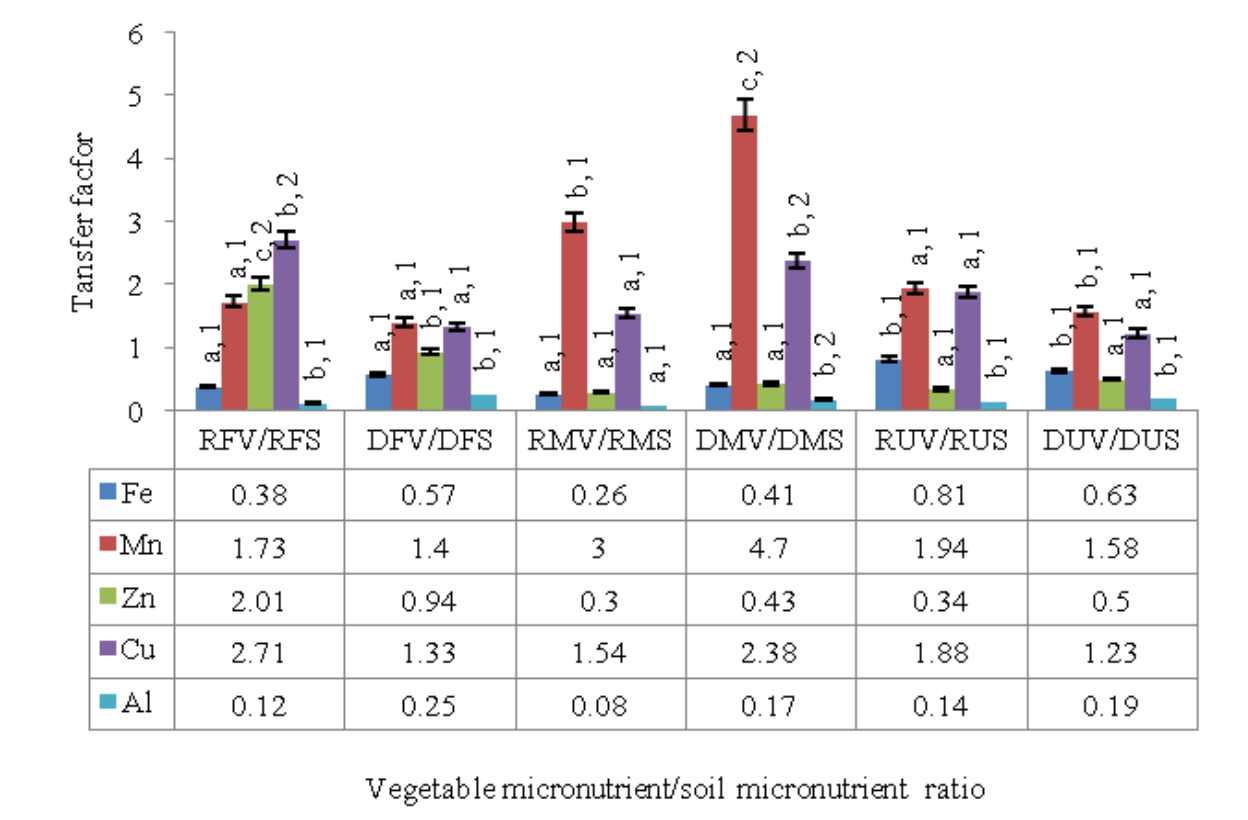

Figure 6. Soil-to-plant micronutrient transfer factors for the different topographic positions and seasons (RFS: Rainy season footslope soils; DFS: Dry season footslope soils; RMS: rainy season midslope soils; DMS: dry season midslope soils; RUS: rainy season upslope soils; DUS: dry season upslope soils; between topographic positions, bars with same shades, followed by different letters are significantly different at $\mathrm{P}<0.05$; within topographic positions (between seasons), bars with the same shade followed by different numbers are significantly different at $\mathrm{p}<0.05$ for different seasons) 
Table 2. Correlation coefficients (r) amongst soil micronutrients concentrations plus soil physico-chemical characteristics for the different sites and seasons

\begin{tabular}{|c|c|c|c|c|c|c|c|c|c|c|c|c|c|c|}
\hline & Clay & $\begin{array}{c}\mathrm{pH} \\
\left(\mathrm{H}_{2} \mathrm{O}\right)\end{array}$ & $\mathrm{OM}$ & $\mathrm{Ca}$ & $\mathrm{Mg}$ & $\mathrm{K}$ & S & CEC & $\begin{array}{c}\text { Avail. } \\
\text { P }\end{array}$ & $\mathrm{Fe}$ & $\mathrm{Mn}$ & $\mathrm{Zn}$ & $\mathrm{Cu}$ & $\mathrm{Al}$ \\
\hline \multicolumn{15}{|c|}{ RFS } \\
\hline $\mathrm{Fe}$ & 0.22 & $0.82 * *$ & $0.60 * *$ & $0.63^{* *}$ & $0.84 * *$ & $0.95^{* *}$ & $0.78^{* *}$ & $0.95^{* *}$ & 0.01 & 1 & $0.76^{* * *}$ & $-0.33^{*}$ & $0.54 * *$ & $0.59 * *$ \\
\hline $\mathrm{Mn}$ & $0.80^{* *}$ & $0.94 * *$ & $-0.84 * *$ & $-0.81 * *$ & $-0.85 * *$ & -0.10 & -0.06 & $0.81 * *$ & $0.79 * *$ & & 1 & $0.32 *$ & $-0.56^{* *}$ & $0.37 *$ \\
\hline $\mathrm{Zn}$ & $0.33^{*}$ & $-0.95^{* *}$ & $-0.63 * *$ & $-0.70 * *$ & $-0.92 * *$ & 0.01 & -0.27 & $-0.89 * *$ & $-0.35^{*}$ & & & 1 & $-0.43 *$ & -0.22 \\
\hline $\mathrm{Cu}$ & $0.92 * *$ & $-0.73 * *$ & $0.96^{* *}$ & $0.77 * *$ & $-0.97 * *$ & -0.25 & $-0.40 * *$ & $-0.98 * *$ & $0.96^{* *}$ & & & & 1 & 0.08 \\
\hline $\mathrm{Al}$ & $-0.95 * *$ & $-0.98 * *$ & $-0.98 * *$ & 0.01 & 0.01 & 0.18 & $0.68 * *$ & -0.27 & 0.16 & & & & & 1 \\
\hline \multicolumn{15}{|c|}{ DFS } \\
\hline $\mathrm{Fe}$ & $0.97 * *$ & $-0.89 * *$ & $-0.66^{* *}$ & $0.59 * *$ & $-0.79 * *$ & 0.26 & $0.47 * *$ & $0.87 * *$ & $0.95 * *$ & 1 & -0.23 & 0.06 & $0.91 * *$ & $0.66^{* *}$ \\
\hline $\mathrm{Mn}$ & $-0.76 * *$ & $-0.98 * *$ & $-0.71 * *$ & -0.04 & $-0.35^{*}$ & $0.44^{*}$ & $0.54 * *$ & $0.75^{* *}$ & 0.23 & & 1 & 0.28 & $-0.89 * *$ & $0.71 * *$ \\
\hline $\mathrm{Zn}$ & $0.99 * *$ & $0.99 * *$ & $0.42 *$ & 0.71 & $-0.96 * *$ & 0.04 & $-0.66 * *$ & $-0.56^{* *}$ & $-0.99 * *$ & & & 1 & $0.32 *$ & $0.99 * *$ \\
\hline $\mathrm{Cu}$ & $0.85^{* *}$ & $-0.95 * *$ & $0.30^{*}$ & $-0.98 * *$ & $0.42^{*}$ & -0.10 & $-0.48 * *$ & -0.27 & $0.99 * *$ & & & & 1 & $0.30^{*}$ \\
\hline $\mathrm{Al}$ & $-0.90 * *$ & $-0.95 * *$ & $-0.58 * *$ & $-0.84 * *$ & $-0.79 * *$ & $0.54 * *$ & $-0.60 * *$ & $-0.87 * *$ & $-0.56 * *$ & & & & & 1 \\
\hline \multicolumn{15}{|c|}{ RMS } \\
\hline $\mathrm{Fe}$ & $0.82 * *$ & $0.83^{* *}$ & 0.24 & 0.16 & $0.78^{* *}$ & $0.62 * *$ & -0.17 & $0.75^{* *}$ & $-0.43^{*}$ & 1 & $0.90 * *$ & $-0.79 * *$ & 0.20 & $0.71 * *$ \\
\hline $\mathrm{Mn}$ & 0.05 & $-0.57 * *$ & $-0.65 * *$ & $-0.86 * *$ & -0.19 & -0.13 & $0.52 * *$ & $0.93 * *$ & $0.98^{* *}$ & & 1 & $0.32 *$ & $-0.86 * *$ & $0.49 * *$ \\
\hline $\mathrm{Zn}$ & 0.16 & $-0.61 * *$ & $0.38 *$ & $-0.98 * *$ & $-0.88 * *$ & 0.10 & $0.87 * *$ & -0.27 & $-0.98 * *$ & & & 1 & -0.10 & $-0.60 * *$ \\
\hline $\mathrm{Cu}$ & $0.72 * *$ & $0.96^{* *}$ & $-0.97 * *$ & $0.93 * *$ & $0.86^{* *}$ & $-0.27 * *$ & $-0.63 * *$ & $-0.70 * *$ & 0.08 & & & & 1 & $0.57 * *$ \\
\hline $\mathrm{Al}$ & $-0.64 * *$ & $-0.68 * *$ & $-0.89 * *$ & -0.27 & $0.55 * *$ & -0.27 & -0.28 & $0.75 * *$ & $-0.89 * *$ & & & & & 1 \\
\hline \multicolumn{15}{|c|}{ RMS } \\
\hline $\mathrm{Fe}$ & $-0.49 * *$ & $0.48 * *$ & $-0.42 *$ & $0.87 * *$ & $-0.99 * *$ & -0.27 & -0.22 & $0.83 * *$ & $-0.49 * *$ & 1 & $0.92 * *$ & $-0.34 *$ & $0.64 * *$ & $0.36^{*}$ \\
\hline $\mathrm{Mn}$ & 0.16 & $-0.70^{* *}$ & $-0.48 * *$ & $0.75 * *$ & 0.16 & 0.24 & $-0.74 * *$ & $-0.57 * *$ & $0.98^{* *}$ & & 1 & $-0.51 * *$ & $0.76^{* *}$ & $0.68 * *$ \\
\hline $\mathrm{Zn}$ & $0.77 * *$ & $0.90^{* *}$ & $0.97 * *$ & $0.93 * *$ & $-0.50 * *$ & $-0.55^{* *}$ & $-0.80 * *$ & $-0.87 * *$ & $0.55^{* *}$ & & & 1 & 0.23 & $0.52 *$ \\
\hline $\mathrm{Cu}$ & $-0.65^{* *}$ & $-0.97 * *$ & $0.58 * *$ & $-0.62 * *$ & -0.23 & -0.26 & 0.17 & -0.26 & $0.60 * *$ & & & & 1 & -0.14 \\
\hline $\mathrm{Al}$ & -0.10 & $0.61 * *$ & $-0.32 *$ & $-0.94 * *$ & $-0.79 * *$ & -0.22 & -0.09 & $-0.93 * *$ & $0.93 * *$ & & & & & 1 \\
\hline \multicolumn{15}{|c|}{ DUS } \\
\hline $\mathrm{Fe}$ & -0.27 & $0.71 * *$ & -0.04 & $0.82 * *$ & $0.82 * *$ & 0.08 & -0.14 & -0.27 & -0.27 & 1 & $0.52 * *$ & $0.54 * *$ & $0.75^{* *}$ & -0.25 \\
\hline Mn & $0.97 * *$ & $0.79 * *$ & $-0.93 * *$ & $0.93 * *$ & $0.91 * *$ & -0.11 & $0.47 * *$ & $0.87 * *$ & 0.24 & & 1 & $-0.33 *$ & 0.09 & 0.18 \\
\hline $\mathrm{Zn}$ & $0.99 * *$ & $-0.59 *$ & $0.32 *$ & $0.97 * *$ & $0.83^{* *}$ & 0.05 & 0.20 & $0.75^{* *}$ & $0.55^{* *}$ & & & 1 & 0.17 & 0.26 \\
\hline $\mathrm{Cu}$ & $0.56^{* *}$ & $-0.80 * *$ & $-0.33^{*}$ & $-0.98 * *$ & $-0.81 * *$ & 0.09 & 0.22 & $0.93 * *$ & 0.26 & & & & 1 & $0.44 *$ \\
\hline $\mathrm{Al}$ & $-0.43^{*}$ & $0.91 *$ & $-0.72 * *$ & 0.08 & $-0.62 * *$ & -0.06 & $0.31 *$ & -0.27 & 0.01 & & & & & 1 \\
\hline \multicolumn{15}{|c|}{ RUS } \\
\hline $\mathrm{Fe}$ & $0.98 * *$ & $0.60 * *$ & $0.58 * *$ & $-0.89 * *$ & $-0.99 * *$ & -0.14 & -0.20 & $0.87 * *$ & $0.59 * *$ & 1 & $0.52 * *$ & $0.54 * *$ & $0.59 * *$ & $0.68 * *$ \\
\hline Mn & $0.99 * *$ & $0.91 * *$ & $-0.98 * *$ & $-0.49 * *$ & -0.21 & 0.27 & 0.26 & $0.66 * *$ & -0.04 & & 1 & $0.67 * *$ & 0.16 & 0.28 \\
\hline $\mathrm{Zn}$ & $-0.45^{* *}$ & $-0.89 * *$ & $0.55^{* *}$ & $-0.96 * *$ & $-0.93 * *$ & -0.04 & -0.21 & $-0.53 * *$ & $0.71 * *$ & & & 1 & -0.17 & -0.14 \\
\hline $\mathrm{Cu}$ & $-0.60 * *$ & $0.32 *$ & $-0.60 * *$ & $0.81 * *$ & -0.23 & -0.08 & $-0.61 * *$ & -0.06 & 0.01 & & & & 1 & 0.24 \\
\hline $\mathrm{Al}$ & $0.98 * *$ & $-0.62 * *$ & $-0.93 * *$ & $-0.58 * *$ & $-0.76 * *$ & $-0.34 *$ & $0.96^{*}$ & 0.28 & $0.59 * *$ & & & & & 1 \\
\hline
\end{tabular}

RFS: Rainy season footslope soils; DFS: Dry season footslope soils; RMS: rainy season midslope soils; DMS: dry season midslope soils; RUS: rainy season upslope soils; DUS: dry season upslope soils; **Significant at the 0.01 level; *Significant at the 0.05 level.

\subsection{Micronutrients Intake Rates}

The daily intake of metals was higher in children than in adults for the same landscape position and season (Figure 7). In adults, the daily intake of Fe was low for all cases, while in children Fe was low only in the rainy season at upslope and midslope.

In adults, based on position, except for DMV and DUV, there was no significant difference between the daily intake rates of $\mathrm{Fe}$ in adults. However, $\mathrm{Fe}$ contents varied significantly $(P<0.05)$ between seasons (Figure $7 \mathrm{a})$. Mn intake rates were not significantly different among positions but were all significantly different among seasons, apart from DFV and DMV. For Zn, only RUV and RMV did not vary significantly from the rest of the vegetables based on positions while season-wise, all the daily intake rates were significantly different among seasons. The daily intake rates of $\mathrm{Cu}$ at footslope were significantly different from the rest of the positions. Season-wise, only the midslope and the upslope daily intake rates varied significantly among seasons. 
Table 3. Correlation coefficients (r) among micronutrients in soil and vegetable for the different sites and seasons

\begin{tabular}{|c|c|c|c|c|c|c|}
\hline & Micronutrients & $\mathbf{F e}$ & Mn & $\mathbf{Z n}$ & $\mathrm{Cu}$ & Al \\
\hline \multicolumn{7}{|c|}{ RFS } \\
\hline \multirow{5}{*}{ RFV } & $\mathrm{Fe}$ & $-0.61 * *$ & $-0.89 *$ & -0.23 & $-0.72 * *$ & $-0.89 * *$ \\
\hline & $\mathrm{Mn}$ & & $0.64 * *$ & 0.16 & 0.21 & $0.78 * *$ \\
\hline & $\mathrm{Zn}$ & & & $0.91 * *$ & -0.12 & $0.54 * *$ \\
\hline & $\mathrm{Cu}$ & & & & $0.65^{* *}$ & $0.62 * *$ \\
\hline & $\mathrm{Al}$ & & & & & 0.17 \\
\hline \multicolumn{7}{|c|}{ DFS } \\
\hline \multirow{5}{*}{ DFV } & $\mathrm{Fe}$ & $-0.67 * *$ & 0.16 & $-0.61 * *$ & $0.32 *$ & 0.23 \\
\hline & $\mathrm{Mn}$ & 0.06 & $-0.66^{* *}$ & 0.14 & $0.56 * *$ & $0.61 * *$ \\
\hline & $\mathrm{Zn}$ & & $-0.56^{* *}$ & 0.22 & -0.29 & $-0.43^{*}$ \\
\hline & $\mathrm{Cu}$ & & & & $0.85^{*}$ & $-0.53 * *$ \\
\hline & $\mathrm{Al}$ & & & & & 0.11 \\
\hline \multicolumn{7}{|c|}{ RMS } \\
\hline \multirow{5}{*}{ RMV } & $\mathrm{Fe}$ & 0.16 & $-0.79 *$ & $0.69 * *$ & $0.55^{* *}$ & $-0.68 * *$ \\
\hline & $\mathrm{Mn}$ & & $0.76^{*}$ & $0.32 *$ & $0.60 * *$ & $0.48 * *$ \\
\hline & $\mathrm{Zn}$ & & & $0.64 * *$ & $0.39 *$ & $-0.70^{* * *}$ \\
\hline & $\mathrm{Cu}$ & & & & $0.93 * *$ & $0.90 * *$ \\
\hline & $\mathrm{Al}$ & & & & & $-0.41^{*}$ \\
\hline \multicolumn{7}{|c|}{ DMS } \\
\hline \multirow{5}{*}{ RUV } & $\mathrm{Fe}$ & $-0.81 * *$ & 0.14 & $0.45^{* *}$ & $-0.87 * *$ & 0.29 \\
\hline & $\mathrm{Mn}$ & & $0.89 * *$ & $0.34 *$ & $0.64 * *$ & $0.66 * *$ \\
\hline & $\mathrm{Zn}$ & & & $0.95 * *$ & -0.22 & $-0.34^{*}$ \\
\hline & $\mathrm{Cu}$ & & & & $0.66 * *$ & $0.89 * *$ \\
\hline & $\mathrm{Al}$ & & & & & $-0.87 * *$ \\
\hline \multicolumn{7}{|c|}{ DUS } \\
\hline \multirow{5}{*}{ DUV } & $\mathrm{Fe}$ & $-0.88 * *$ & $-0.73 * *$ & -0.10 & $-0.86^{* *}$ & -0.16 \\
\hline & $\mathrm{Mn}$ & & $0.32 *$ & $0.60 * *$ & 0.21 & -0.20 \\
\hline & $\mathrm{Zn}$ & & & 0.22 & $0.67 * *$ & $0.32 *$ \\
\hline & $\mathrm{Cu}$ & & & & $0.71 * *$ & 0.22 \\
\hline & $\mathrm{Al}$ & & & & & $-0.49 * *$ \\
\hline \multicolumn{7}{|c|}{ RUS } \\
\hline \multirow{5}{*}{ RUV } & $\mathrm{Fe}$ & $-0.53 * *$ & $-0.83 * *$ & 0.03 & $-0.52 * *$ & $-0.42^{*}$ \\
\hline & $\mathrm{Mn}$ & & $0.54 * *$ & -0.05 & $0.82 * *$ & $0.59 * *$ \\
\hline & $\mathrm{Zn}$ & & & $-0.41 *$ & $0.59 * *$ & -0.21 \\
\hline & $\mathrm{Cu}$ & & & & 0.08 & -0.24 \\
\hline & $\mathrm{Al}$ & & & & & $-0.72 * *$ \\
\hline
\end{tabular}

RMS: rainy season midslope soils; DMS: dry season midslope soils; RUS: rainy season upslope soils; DUS: dry season upslope soils; RFV: Rainy season footslope vegetables; DFV: Dry season footslope vegetables; RMV: rainy season midslope vegetables; RUV: rainy season upslope vegetables; DUV: dry season upslope vegetables.

In Children, all the daily intake rates of Fe and Mn were significantly different among positions. Season-wise, all the intake rates were significant different between seasons and topographic positions (Figure 7b).

For Zn, apart from DUV and RMV, all other daily intake rates were significantly different among positions but all the values were significantly different among seasons within each topographic position.
For $\mathrm{Cu}$, DUV, RUV and RMV did not vary significantly unlike the rest of the daily metal intake rates. Within each topographic position, footslope and midslope values were significantly different among seasons. Finally, the daily intake rates of $\mathrm{Al}$ varied significantly between topographic positions but only footslope showed a seasonal significant variation $(P<0.05)$. 

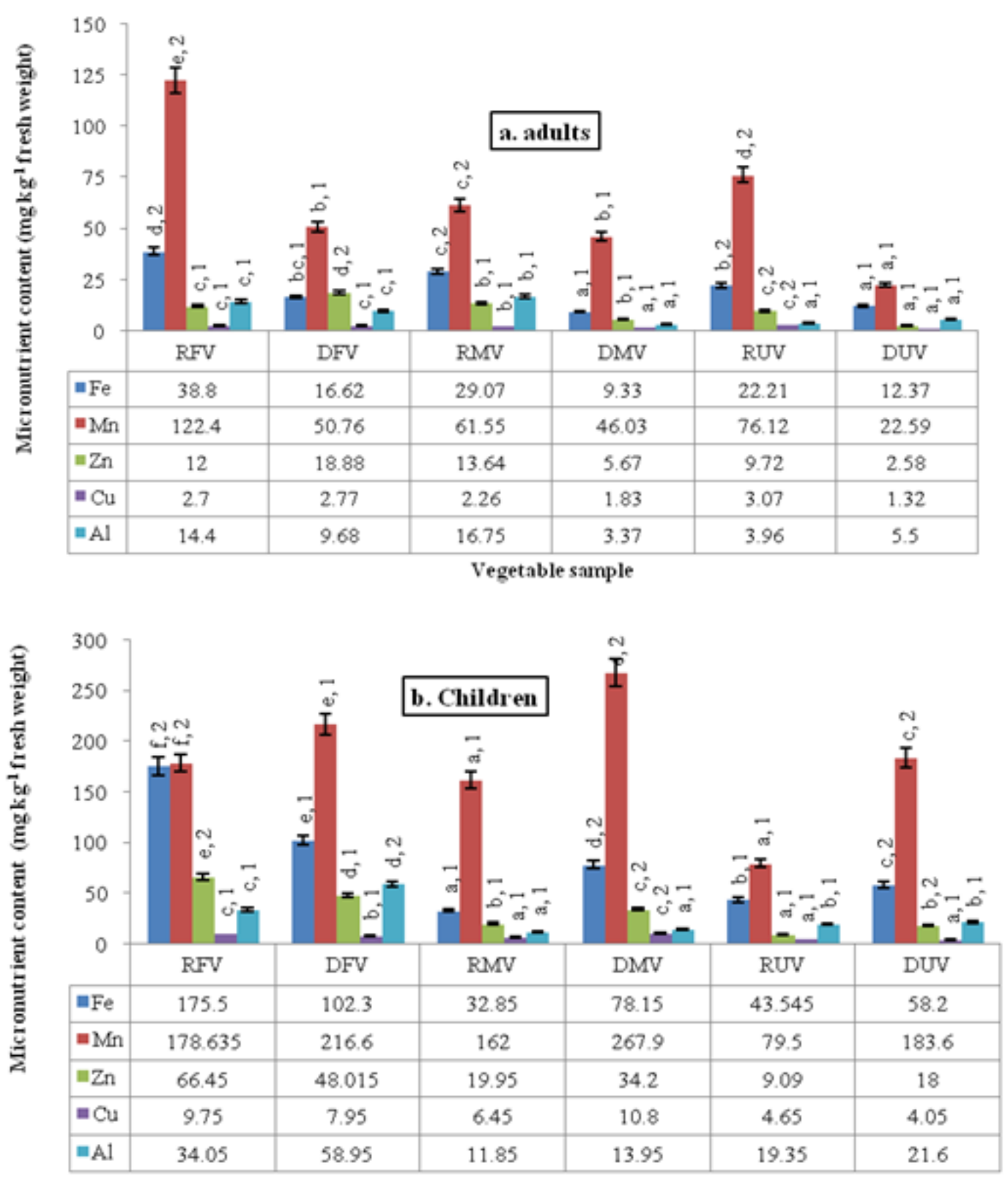

Vegetable sample

RFV: Rainy season footslope vegetables; DFV: Dry season footslope vegetables; RMV: rainy season midslope vegetables; $D M V$ : dry season midslope vegetables; RUV: rainy season upslope vegetables; DUV: dry season upslope vegetables. Between topographic positions, bars with same shades, followed by different letters are significantly different at $P<0.05$; within topographic positions (between seasons), bars with the same shade followed by different numbers are significantly different at $p<0.05$ for different seasons).

Figure 7. Average daily intake of micronutrients through vegetable consumption in Bafut (a) adults; (b) children

\section{Discussions}

\subsection{Soil Properties along the Soil Catena}

All the studied soils revealed a uniform particle density in all topographic positions, but porosity was slightly lower for the footslope soils. This could be due to lateral migration and accumulation of fine clayey materials at the lower positions leading to an increase in bulk density of the soils. The studied soils revealed a silt/clay ratio above 0.15 or 0.20 indicating that the soils are relatively young with high degree of weathering potential, respectively $[60,61,62,63,64]$. The $\mathrm{pH}$ values were globally below 5 revealing very acidic soils [7]. Leaching of bases under high rainfall and warm temperature, typical of tropical ecosystems, is the primary cause of soil acidic reactions [65]. The OC contents were very high in all the soils and decreased with increased slope with lowest values recorded at mid-slope and results matched the findings of $[2,4,64]$. Soil texture has a strong influence on soil's ability to store and amass soil organic carbon [65]. The exchangeable cations were higher at the footslope than the upper positions. This might imply leaching from the upper landscape positions and deposition at the footslope [65]. Also, the basic cations were higher in the dry season compared to the rainy season at different positions and these agrees with abundant rainfall in the rainy season that leaches upper landscapes and enriches the lower positions with basic cations [66]. 


\subsection{Micronutrient Concentrations of Soils along the Soil Catena}

The Fe contents were high for all the positions and seasons according to [59], and fell within the permissible range of agricultural soils [72] as well as above the critical limits for plant growth [73]. The $\mathrm{Fe}$ contents of soil usually range between $200 \mathrm{mg} \mathrm{kg}^{-1}$ and $100000 \mathrm{mg} \mathrm{kg}^{-1}$ [74]. Apart from the upslope rainy season soils in Bafut, all soil Fe levels were higher than the 21.4-58.9 mg kg-1 reported for some contaminated soils in Jos (Nigeria) by [75] but lower than Fe contents documented for vegetable soils of the Cameroon inland valleys of the Nkoup River in Foumbot [29] and Mezam River in Bamenda [25]. Fe availability under stress conditions in some soils is enhanced through the production of organic chelating agents by microorganisms [76]. Fe deficiency is common in neutral to alkaline soils [77]. The high Fe concentration of the Bafut soils might therefore be related to their acidic nature, conditions favorable for $\mathrm{Fe}$ accumulation. The main sources of $\mathrm{Fe}$ are probably the parent rocks, iron pipes, waste can containers and rusted iron rods commonly dumped into nature following rapid population growth in the Bafut Sub-division as well as Fe present in irrigation water [78]. Fe deficiency, thus, is not likely to occur on vegetables grown on these soils.

Mn was the most concentrated micronutrient in the S. scabrum, ranging between 53 and $178.6 \mathrm{mg} \mathrm{kg}^{-1}$. The highest contents were observed for DMV while the lowest ones were shown by the RUV implying a possibly higher $\mathrm{Mn}$ absorption in the dry season compared to the rainy season. Apart from RUV, the Mn contents of the rest of the vegetables did not vary significantly site-wise. Between seasons, the Mn contents were significantly different for all the sites revealing that seasonal changes play a vital role on $\mathrm{Mn}$ availability and absorption. These values were however within the intervals required for normal plant growth [79], but fell far below the toxicity level in plants [80] indicating a normal plant growth. Generally, the concentration of $\mathrm{Mn}$ in soil covers a particularly wide range, from as little as $20 \mathrm{mg} \mathrm{kg}^{-1}$ to well over $3000 \mathrm{mg} \mathrm{kg}^{-1}$ [74]. The lowest limits are typical of severely leached acid soils meanwhile Mn toxicities are common in unleached acid soils and waterlogged conditions; severe Mn deficiency is common in alkaline and calcareous soils [10,77]. Soil $\mathrm{pH}$ is therefore one of the main factors determining Mn availability in soils [65]. A $\mathrm{pH}$ value below 6.0 favours $\mathrm{Mn}$ reduction and formation of the more available divalent ion $\left(\mathrm{Mn}^{2+}\right)$; a higher $\mathrm{pH}$ favours $\mathrm{Mn}$ oxidation to $\mathrm{Mn}^{4+}$ ion, forming the insoluble oxides like $\mathrm{MnO}_{2}, \mathrm{Mn}_{2} \mathrm{O}_{3}$ and $\mathrm{Mn}_{3} \mathrm{O}_{4}$ [65,74]. The high $\mathrm{Mn}$ contents of vegetables recorded in the present study could be related to the soil acidic $\mathrm{pH}$ [81].

The mean soil $\mathrm{Zn}$ contents in all the topographic positions were high based on the critical values of [59]. Generally, in most of the positions, $\mathrm{Zn}$ was irregularly distributed in others. It was below the permissible range for agricultural soils [72] and generally above the critical levels recommended for agriculture [73]. Similar results have been documented $[2,4,6]$. Certain soil conditions might reduce $\mathrm{Zn}$ availability, notably high $\mathrm{pH}$ as the solubility of $\mathrm{Zn}$ decreases with increase $\mathrm{pH}$ [10]. Thus, a high incidence of $\mathrm{Zn}$ deficiency often occurs on calcareous or limed soils while excessive levels are common on very acid soils $(<\mathrm{pH} 5.0)$ or in areas where zinc-enriched municipal sewage sludge or industrial waste have been added to cropland as soil amendment [27,77].

The $\mathrm{Cu}$ contents in the Bafut soils were medium to high [59], fell below the permissible range for agricultural soils [72] and below the critical levels for agricultural soils [73]. These results are similar to those reported by [34]. S. scabrum is particularly sensitive to $\mathrm{Cu}$ deficiencies [82]. Soils derived from basic rocks usually show low $\mathrm{Cu}$ contents whereas acid rocks favour $\mathrm{Cu}$ availability [74]. Factors affecting the soils ability to provide $\mathrm{Cu}$ to plants include $\mathrm{pH}$, humus content and proportion of sand to clay [65]. $\mathrm{Cu}$ deficiency is most common on highly calcareous soils as well as in sandy soils with low organic matter contents [82]. These findings are consistent with those of the studied area. High contents of other metals Fe, $\mathrm{Mg}$ and $\mathrm{Al}$ in soil can induce $\mathrm{Cu}$ deficiency due to ionic balance effect $[10,74]$.

The Al concentrations of the soils were very high and this was unfailingly related to the soil's strong acidity [52]. However, the Al toxicity of Kamprath [53] fell within the moderate range indicating that $\mathrm{Al}$ tolerant plants could grow on such soils. In such acid soils, the Al concentration increases drastically, becomes toxic and disturbs root growth and functions. Soil $\mathrm{pH}$ is the most important factor that influences the form of $\mathrm{Al}$ present in soils [84-89].

Soil $\mathrm{pH}\left(\mathrm{H}_{2} \mathrm{O}\right)$ values below 5.5 are accompanied by numerous phenomena, such as increased abundance of $\mathrm{Al}$ and $\mathrm{Mn}$, reduced amounts of basic cations, reduced solubility of phosphorous and molybdenum and the inhibited root growth [10]. Significantly high clay contents and available phosphorus might increase risk of Al toxicity at low $\mathrm{pH}[10]$. At low $\mathrm{pH}$, organic matter could buffer Al toxicity by forming chelates with it, thus reducing excess $\mathrm{Al}$ from being taken up by plants $[86,87,88]$. However, in the present study, despite the highest $\mathrm{pH}$, clay contents, exchangeable cations and CEC of the footslope soils, they showed the highest $\mathrm{Al}$ concentrations. This might be due to site-specific features responsible and a possible migration of excess $\mathrm{Al}$ from the upper landscapes to the valleys [10]. These Al concentrations are higher than those reported elsewhere by [89], perhaps because of the acidic $\mathrm{pH}$ of the Bafut soils which could be stimulating dissolution of $\mathrm{Al}$ species. These high values are typical of volcanic soils where Al commonly forms complexes with organic material to leading to an increase in its stability [65]. The acidic character of Bafut soil might be influenced by several agricultural practices conducted by farmers.

The Fe/Mn ratios were greater than 2.5 for all the midslope soils but less than 1.5 for all footslope soils, no matter the season. This revealed a potential Fe toxicity to plants in the midslope and a potential Mn toxicity to plants at the footslope [10]. For the upslope soils, the $\mathrm{Fe} / \mathrm{Mn}$ ratios fell between 1.5 and 2 , indicating that none of the two micronutrients were toxic to plants at this landscape position [10]. This Fe/Mn trend from upslope to footslope could be directly linked to soil controlling factors which are both intrinsic (clayey to heavy clayey texture, relative humidity, mediocre porosity, acidic $\mathrm{pH}$, high organic matter content, degree of slaking, structural 
stability, etc) and extrinsic (high precipitation, temperature, gradient of slope, etc). These factors influence the solubility and mobility of soil micronutrients and subsequent availability for plants absorption [90].

\subsection{Vegetable Micronutrient Levels along the Soil Catena}

The Fe contents in S. scabrum ranged from 21.9 to 68.2 $\mathrm{mg} \mathrm{kg}^{-1}$ and were the second most represented element in the vegetable samples from the studied sites after Mn. The highest Fe contents were observed for DFV and the lowest ones were shown by the RMV. These trends might be related to depletion of iron by rain water and subsequent accumulation in the footslope, which begin to precipitate during the dry season [65]. This might, thus, explain why there was a season-wise significant difference in $\mathrm{Fe}$ contents between the midslope and valley vegetables. Apart from dry season vegetables in upslope and valley, the remaining treatments were below the normal range required for plant growth [79], very far below the toxicity levels [80] and will therefore not pose any problems to consumers as Food [91]. The low $\mathrm{Fe}$ contents of $S$. scabrum compared to the soils could be due to the naturally high organic matter contents at soil surface, which at low $\mathrm{pH}$, favours the formation of organo-metallic complexes with $\mathrm{Fe}$, thereby blocking its uptake by plants [92]. In the footslope, the Fe contents were lower than those already documented in Ngaoundéré (North Cameroon) by [93] and [8], but very far below those reported by [25] on vegetables grown along the Mezam River in Bamenda. These metal values were also lower than those reported in Kenya and Tanzania [8] and in Nigeria [83]. The Mn contents in the Bafut S. scabrum were extremely high relative to values reported for some vegetables in India [15,24] and Russia [94]. Globally, the dry season $S$. scabrum showed higher Mn contents than those grown in the rainy season. The metal contents of vegetables fell within the sufficiency levels and below the toxicity levels for optimum plant growth [79] as well as within the permissible levels in food [91]. Mn and Fe are essential mineral elements for both plants and animals, and the recorded levels in this study indicate that the vegetables constitute very good sources of nutrients for the population.

The Zn concentrations of S. scabrum fell below the critical range for optimum plant growth [14] as well as the permissible level in food [91]. All the S. scabrum samples contained inadequate $\mathrm{Zn}$ levels [79]. These observed values were in agreement with those published by [8] and [82] but were higher than values reported by [25] on vegetables grown along the Mezam River valley in Bamenda. This $\mathrm{Zn}$ levels were also analogous to the 25.2-50.0 mg kg ${ }^{-1}$ reported for $S$. scabrum in India [15,24], higher than values recorded on vegetables in Nigeria [95], Egypt [97] and Latin America [97]. Zn deficiency has been reported on crops growing where calcareous subsoils have been exposed by land leveling or erosion, or where subsoil is mixed with topsoil [77].

The $\mathrm{Cu}$ contents of $S$. scabrum were very low compared to the other metals. The footslope vegetables fell within the normal level in plant growth [79] and below the toxicity level [80], but fell within the permissible level for human consumption [91]. For the midslope, RMV fell below the normal level in plants and RMV fell within normal level, but both were within the permissible levels in food [91]. The upslope vegetables fell below the normal level and toxicity limits [80], but fell within the permissible level in food (FAO/WHO 2001). These values were close to those reported by [93] in Ngaoundéré (North Cameroon), but higher than those of [29] for vegetables grown along the Nkoup River valley in Foumbot (West Cameroon). This range fell within values for vegetables irrigated with wastewater [25]. The $\mathrm{Cu}$ content of most agricultural soils ranges from 2 to $100 \mu \mathrm{g} / \mathrm{g}[74,98]$.

Although the vegetable $\mathrm{Al}$ contents were far below those of the studied soils, they were extremely high compared to the permissible limit of $1.00 \mathrm{mg} \mathrm{kg}^{-1}$ in food [91]. These results were contrary to expectations considering that the soils of the area showed low $\mathrm{pH}$, high organic matter, high available phosphorus and high exchangeable $\mathrm{Ca}$ which are conditions that hinder $\mathrm{Al}$ uptake by roots. Even so, mechanisms controlling $\mathrm{Al}$ uptake, tolerance and toxicity are numerous and complicated due to the complex chemistry of $\mathrm{Al}$ according to [86]. The long-term human intake of such vegetable with high $\mathrm{Al}$ contents could causes problems in humans as nervous system, lungs, and kidney. Strong accumulation in humans could lead to Alzheimer's disease, Parkinson's disease, etc [91].

The metal transfer factors were above 1 for $\mathrm{Cu}$ and $\mathrm{Mn}$ in the studied soils implying a relatively higher concentration of those two metals in the vegetables compared to the soils. $\mathrm{Zn}$ showed a transfer factor above 1 only for the rainy season footslope soils. The rest of the horizons showed transfer rates below 1. Similar findings [25] along the Mezam river valley in Bamenda town revealed very high metal transfer factors for $\mathrm{Zn}\left(4.58-7.09 \mathrm{mg} \mathrm{kg}^{-1}\right.$ dry weight) and $\mathrm{Cu}\left(0.69-1.62 \mathrm{mg} \mathrm{kg}^{-1}\right.$ dry weight) compared to Bafut, while the Fe and Mn factors were comparable. The differences may result from vegetable irrigation with contaminated water in the Bamenda Urban Centre which leads to the deposition of excess plant micronutrients in the soils.

Most of the soil micronutrients showed strong correlations with other soil micronutrients and physicochemical characteristics. Between vegetables and soils, Mn, $\mathrm{Zn}$ and $\mathrm{Cu}$ correlated positively amongst themselves and with most of the other metals in agreement with the high transfer factors of these three micronutrients compared to $\mathrm{Fe}$ and $\mathrm{Al}$. However, numerous redundancies were observed in soil and vegetable data correlations attributable to many causes such as site-specific biogeochemical characteristics, previous land management systems, biotic activity and small size of samples used. Amundson et al. [99] attributed such behavior of soil properties to the agriculture imprint on the critical zone. Biogeochemical processes in the critical zone affect the metal speciation thereby controlling their solubility, mobility, bioavailability and toxicity hence making their distribution in the critical zone very complex [100]. Thus, Metal ions in soil solution may undergo numerous pathways: plant uptake or retention on surfaces of minerals, natural organic matter, and microbes or leaching into groundwater or by colloidfacilitated transport, or even precipitation into solid phases or finally diffusion in porous media such as soils. 


\subsection{Influence of Slope and Seasons on Soil Micronutrient Levels and Uptake by Plants and Humans}

The footslope soils showed a slightly higher bulk density, lower porosity and a lower sandy fraction. Based on the silt/clay ratio, the relatively younger age of the midslope was consistent with a steep slope that favours erosions and continuous rejuvenation of the soil [65]. Soil acidity did not vary much along the slope. Organic matter content did not vary much among seasons but was highest at the footslope and least at midslope. Basic cations, sum of bases, CEC and base saturation were slightly higher at the rainy season and at the footslope but least at the midslope. Available P was higher in the dry season apart from the footslope but the lowest levels appeared in the midslope. The footslope and upslope showed a more stable structural stability compared to the midslope. Apart from soil $\mathrm{Cu}$ and $\mathrm{Zn}$ that showed higher levels at midslope, the other metals revealed a higher accumulation at the footslope and a global leaching of the midslope. All the micronutrients were highly concentrated in the dry season, apart from Al, for all topographic positions. The micronutrient concentrations of $S$. scabrum were higher in the dry seasons for all metals apart from $\mathrm{Cu}$ and $\mathrm{Zn}$ at footslope. The metal transfer factors of most of the metals in $S$. Scabrum were higher in the dry season, except for $\mathrm{Fe}$ at upslope, $\mathrm{Mn}$ at footslope and upslope, $\mathrm{Zn}$ at footslope and $\mathrm{Cu}$ at footslope and upslope. These results were concomitant with the average daily consumption rates which were highest in the dry season for most of the topographic positions in children and adults. The influence of topography and seasons on spatial variations of soil properties and bioavailability of plant nutrients has already been reported $[1,3,4,10]$. The results of the correlation coefficients analysis enabled to explain most of the trends from soil to plant and finally to human consumption, but not others due to the presence of numerous redundancies in data. The influence of topography and climate on the pedogenetic process has been highlighted by [65]. These factors affect plants through rate of micronutrients uptake, levels of nutrients in the vegetables and subsequent human daily intake though vegetable consumption. According to [4] slope is the main factor contributing to the transportation and accumulation of fine soil particles when soil organic matter content and structural stability are low thus contributing to upslope "cleansing" and footslope enrichment.

\subsection{Micronutrient Daily Intake Rates}

Except for $\mathrm{Fe}$ and $\mathrm{Zn}$ in adults, most of the daily micronutrient intake rates in all topographic positions were above the recommended daily dietary allowance of the FAO/WHO $[91,101]$ for both children and adults. The children mean daily intake was higher than that of adults and this could be linked to the relatively smaller body weight of children. This indicates excess intake of those micronutrients into the body for the inhabitants of the area calling for more attention to be taken to minimize metal contamination especially for $\mathrm{Mn}, \mathrm{Cu}$ and $\mathrm{Al}$ in adults and all the metals in children. The approach to estimate metal intake could have presented some limitations considering that the cooking and frying process might positively or negatively affect some of the micronutrient concentrations. The daily micronutrient intake rates were too high compared to those already reported for some African indigenous vegetables by $[25,29]$.

\section{Conclusion}

This main objective of this work was to study the effects of different topographic positions and seasons (dry or humid) on micronutrient levels in soils and Solanum scabrum. The main results revealed that the micronutrient levels were lowest for the midslope soils in relation to its steeper gradient that affects downwards migration of matter. $\mathrm{Zn}$ and $\mathrm{Cu}$ were below the recommended range for agricultural soils, while $\mathrm{Al}$ fell far above in relation to the strongly acidic $\mathrm{pH}$. In $S$. scabrum, micronutrients appeared as $\mathrm{Mn}>\mathrm{Fe}>\mathrm{Zn}>\mathrm{Al}>\mathrm{Cu}$. Globally, vegetable metals levels were higher in the dry season for all positions. Except for $\mathrm{Al}$, all metals were below permissible and toxicity levels in food, while only $\mathrm{Fe}, \mathrm{Mn}$ and $\mathrm{Zn}$ where above recommended range for normal plant growth. Metal transfer factors, apart from midslope, were higher in the dry season. Only Mn and Zn for all positions and seasons as well as $\mathrm{Zn}$ at footslope, were above 1 . The micronutrient levels in soils and vegetables were generally higher in the dry seasons for all positions. Micronutrient daily intake rates were higher in the dry season for all positions but lowest in the midslope for all seasons. Except $\mathrm{Fe}$ and $\mathrm{Zn}$ in adults, metal levels were above the recommended daily dietary intake indicating excess micronutrients intake by the inhabitants. Overall, a combination of steep slope and humid season reduces soil micronutrient level, limit uptake by vegetables and hence reduce mean daily intake in humans.

\section{Competing Interests}

The authors declare no conflict of interests.

\section{References}

[1] Biswas, A., Si, B.C, "Revealing the controls of soil water storage at different scales in a Hummocky landscape", Soil Sci Soc Am J 75, 1295-1306, 2011.

[2] Biwe, E.R, "Status and distribution of available micronutrients along a toposequence at Gubi Bauchi North Eastern Nigeria", Int Res J Agric Sc and Soil Sc 2(10), 436-439, 2012.

[3] $\mathrm{Hu}, \mathrm{W}$. and $\mathrm{Si}, \mathrm{B} . \mathrm{C}$, "Revealing the relative influence of soil and topographic properties on soil water content distribution at the watershed scale in two sites", J. Hydrol 516, 107-118, 2014.

[4] Baskan, O., Mayis, O. and Gunturk, A, "Effects of toposequence and land use-land cover on the spatial distribution of soil properties" Env Earth Sciences, 75, 448, 2016.

[5] Rodriguez-Iturbe, I., D'odorico, P., Porporato, A. and Ridolfi, L, "On the spatial and temporal links between vegetation, climate, and soil moisture" Water Resour Res 35, 3709-3722, 1999.

[6] Bvenura, C., Afolayan, A.J, "Mineral uptake in Solanum nigrum L. cultivated on fertilizer amended soils of the Eastern Cape, South Africa", Journal of Applied Botany and Food Quality, 87, 220-226, 2014.

[7] Beernaert, F. and Bitondo, D, "Simple and practical methods to evaluate analytical data of soil profiles". Belgian Cooperation University of Dschang, Dschang, Cameroon, 1991, 66p. 
[8] Kamga, T.R., Kouamé, C., Atangana, A.R., Chagomoka, T. and Ndango, R, "Nutritional evaluation of five African indigenous vegetables", Journal of Horticultural Research, 21(1), 99-106, 2013.

[9] Devkota, B. and Schmidt, G.H, "Accumulation of heavy metals in food plants and grasshoppers from the Taigetos Mountains", Greece. J Agric. Ecosyst Environ, 78, 85-91, 2000.

[10] Hodges, S.C, "Soil fertility basics. Soil extension" North Carolina State University, North Carolina, USA, 2010.

[11] Sobrado, M.A, "Soil and leaf micronutrient composition in contrasting habitats in podzolized sands of the Amazon Region", American Journal of Plant Sciences, 4, 1918-1923, 2013.

[12] Lucas, R.E. and Davis, J.F, "Relationships between $\mathrm{pH}$ values of organic soils and availabilities of 12 plant nutrients", Soil Science, 92, 177-182, 1961.

[13] Latham, M, "Role du facteur sol dans le dévéloppement du cottonier en Cote d'Ivoire" Cahiers ORSTOM, Série Pédologique, 11(1), 29-42, 1971

[14] Landon, J.R, "Booker tropical soil manual: A handbook for soil survey and agriculture evaluation in the tropics and sub-tropics" Longman, Harlow, UK, 1984.

[15] Fiona MM, Singh A, Sharma RK, Agrawal M (2010) Risk assessment of heavy metal toxicity through contaminated vegetables from waste water irrigated area of Varanasi, India. Trop Ecol 51(2), 375-387.

[16] Jimoh, T.O., Ndamitso, M.M., Abdullahi, S.H. and Bankole, M.T, "Determination of copper, iron and lead levels in selected vegetables obtained from the three main markets, in Minna, North Central Nigeria", African Journal of Food Science, 6(23), 554-559, 2012.

[17] Fasuyi, O.A, "Nutritional potentials of some tropical vegetable leaf meals: Chemical characterization and functional properties". Afr J Biotechnol, 5, 49-53, 2006.

[18] Kimatu, J.N, "Correlating aluminum toxicity, heterosis and epigenetic mechanisms in maize yield improvement in acid soils". Biotechnology and Molecular Biology Reviews, 10(2), 12-18, 2015.

[19] Schippers, R. "Notes on huckleberry, Solanum scabrum and related black nightshade species". Natural resources institute University of Greenwich, Greenwich, UK, 1998.

[20] Fontem, D.A., Berinyuy, J.E. and Schippers, R.R, "Selecting promising varieties from farmer's landraces-an experience from Cameroon". FASA/CUDs, Dschang, Cameroon, 2002.

[21] Okeno, J.A., Chebet, D.K. and Mathenge, P.W, "Status of indigenous vegetables in Kenya". Acta Hortic, 621, 9, 2003.

[22] Kocak, S., Tokusoglu, O. and Aycan, S, "Some heavy metal and trace essential element detection in canned vegetable foodstuffs by differential pulse polarography (DPP)". Electronic J Environ Agric Food Chem, 4, 871-878, 2005.

[23] Radwan MA, Salama AK "Market based survey for some heavy metals in Egyptian fruits and vegetables". Food Chem Toxicol, 44, 1273-1278, 2006

[24] Singh, B.K. and Taneja, S.K, "Concentration of $\mathrm{Zn}, \mathrm{Cu}$, and $\mathrm{Mn}$ in vegetables and meat foodstuffs commonly available in Manipur: a North Eastern state of India". Electronic Journal of Environmental, Agricultural and Food Chemistry, 9(3), 610-616, 2010.

[25] Tita, M.A., Tsala, G.N. and Kamgang, K.V.B, "Levels of metals in huckleberry (Solanum scabrum) grown along the Mezam river banks Bamenda, North-West Cameroon: implications for crops growth and human consumption". Syllabus Review, 2 (2), 69-78, 2011.

[26] Adnan Iqbal, M., Nawaz Chaudary, M., Shujah Zaib, Imran M., Khurram Ali, Iqbal, A. et al. "Accumulation of Heavy Metals (Ni, $\mathrm{Cu}, \mathrm{Cd}, \mathrm{Cr}, \mathrm{Pb}$ ) in Agricultural Soils and Spring Seasonal Plants, Irrigated by Industrial Waste Water". J Env Tech Man, 2, 3-10, 2011.

[27] Chiroma, T.M., Ebewele, R.O. and Hymore, F.K, () Levels of heavy metals $(\mathrm{Cu}, \mathrm{Zn}, \mathrm{Pb}, \mathrm{Fe}$ and $\mathrm{Cr})$ in bush green and roselle irrigated with treated and untreated urban sewage water. International Research Journal of Environment Sciences, 1(4), 50-55, 2012.

[28] Tita, M.A., Azinwi Tamfuh, P., Wotchoko, P., Magha, MA, Bienkaa Azinwi, R, "Micronutrient Composition of Soils and Supported Solanum scabrum in Bafut Sub-division (North-West Cameroon)". Int J Pl Soil Sc, 9(3), 1-14, 2015.

[29] Tita, M.A., Tsala, G.N. and Kamgang, K.V.B, "Levels of heavy metals in vegetables grown along the Nkoup River banks in
Foumbot, Western Cameroon: Implications for crop growth and human consumption", in Proceedings of the 5th Conference of the Africa Soil Science Society. Soils and new challenges for Sustainable Development in Africa, ASSS, 57, 2009.

[30] Nazir, R., Khan, M., Masab, M., Rehman, H.U., Rauf, N.U., Shahab, S, et al. "Accumulation of Heavy Metals $(\mathrm{Ni}, \mathrm{Cu}, \mathrm{Cd}, \mathrm{Cr}$, $\mathrm{Pb}, \mathrm{Zn}, \mathrm{Fe}$ ) in the soil, water and plants and analysis of physicochemical parameters of soil and water Collected from Tanda Dam kohat”. J Pharm Sci Res, 7(3), 89-97, 2015.

[31] Lombin, G, "Evaluating the micronutrient fertility of Nigeria's semi-arid savanna soils". Soil Science, 136 (1), 42-45, 1983.

[32] Aduloju, M.O, "Extractable micronutrients in the soils of Bolorunduro catena, Ilorin, Kwara State, Nigeria". Biosearch research Communications, 12(2), 139-143, 2000.

[33] Aduloju, M.O. "Acid extractable micronutrients ( $\mathrm{Mn}$ and $\mathrm{Zn}$ ) in selected soils of vegetable producing areas in Kwara State, Nigeria". Nigerian Journal of Horticultural Science, 9, 116-119, 2004.

[34] Aduloju, M.O. and Abdulmumini, A.A, "Distribution of organic and available forms of phosphorous and micronutrients in the soils of a toposequence in Mokwa, Niger State, Nigeria", in Proceedings of the International Soil Tillage Research Organisation (ISTRO), Aduloju, M.O. and Abdulmumini, A.A, (ed.), Nigeria Symposium, Akure, 3-6 November 2014, Nigeria Distribution of Organic and Available Forms of Phosphorous and Micronutrients in the Soils of a toposequence in Mokwa. ISTRO, Niger State, Nigeria, pp. 256-264, 2014.

[35] Akan, J.C., Abdulrahman, F.I., Ogugbuaja, V.O., Ayodele, J.T, "Heavy metals and anion levels in some samples of vegetable grown within the vicinity of Challawa Industrial Area, Kano State, Nigeria”. Am J Appl Sci, 6(3), 534-542, 2009.

[36] Anita, S., Rajesh, K.S., Madhoolika, A. and Fiona, M.M, "Risk assessment of heavy metals toxicity through contaminated vegetable from waste water irrigated area of Varanasi, India". Int Soc Trop Ecol, 51(2), 375-387, 2010.

[37] Anonymous, "Presentation of the Bafut Village Community Project". VCP, Bafut, Cameroon, 2005.

[38] Etia, P.M, "Climate and climatic zones of Cameroon" Jeune Afrique, Paris, France, 1980.

[39] Letouzey, R, "Phytogeographic map of Cameron" Jeune Afrique, Paris, France, 1980.

[40] Acho-Chi C. "Human interference and environmental instability addressing consequences of rapid urban growth in Bamenda". Environment and Urbanization, 10(2), 161-174, 1998.

[41] Olivry, J.C, "Rivers and Streams of Cameroon", MESRESORSTOM, Paris, France, 1986.

[42] Morin, S, "Geomorphological map of Bafut", Jeune Afrique, Paris, France, 1980.

[43] Nougier, J, “Geological map of Cameroon”, Afrique, Paris, France, 1980.

[44] Gavaud, M. and Muller, J.P, "Soil map of Cameroon", Jeune Afrique, Paris, France, 1980.

[45] FAO, "Guidelines for soil description, a framework for international classification, correlation and communication". FAO, Rome, Italy, 2006.

[46] McLean, E.O, "Soil pH and lime requirement", In Methods of soil analysis, Buxton, D.R, (ed.), American Society of Agronomy Inc. and SSSA Inc, Madison, USA, 1982.

[47] Walkey, A., and Black, I.A, "Determination of organic matter in soil". Soil Sci, 37, 549-556, 1934.

[48] Bremner, JM. and Mulvaney, C.S, “Total nitrogen", In Methods of soil analysis, Buxton, D.R, (ed.), American Society of Agronomy Inc. and SSSA Inc, Madison, USA, 1982.

[49] Olsen, S,R. and Sommers, L.E, "Phosphorus", In Methods of soil analysis, Page, A.L., Buxton, R.H., Miller, Keeney, D.R, (Eds.), Am soc Agron, Madison, USA, 403-430, 1980 .

[50] Thomas, G.W, "Exchangeable cations", in Methods of soil analysis, Page, A.L., Buxton, R.H., Miller, Keeney, D.R, (Eds.), Am soc Agron, Madison, USA, 159-165,1982.

[51] Rhoades, J.D, Cation exchanges capacity, in "Methods of soil analysis", Page, A.L., Buxton, R.H., Miller, Keeney, D.R, (eds), Am soc Agron, Madison, USA, 149-158, 1982.

[52] SSA, "Methods of soil analysis", In Chemical methods, Sparks, D.L, (ed), Aluminum, SSA, Madison, 517-550, 1996.

[53] Kamprath, "Soil acidity and liming in soils of humid tropics", Nat Acad of Sc, Washington DC, USA, 1972. 
[54] Pieri, C.J.M.G, "Fertility of soils: a future for farming in the West African savannah", Springer-Verlag, Berlin, Germany, 1992.

[55] Remy, J.C. and Marin-Lafleche, A, "L'analyse de terre: realization d'un programme d'interpretation automatique", Annales agronomiques 25 (4), 607-632, 1976.

[56] US EPA, "SW-846 Method 3050B. Standard operating procedure for the digestion of soil/sediment using hotplate/beaker digestion technique", US EPA, Chicago, USA, 1999.

[57] Jones, B.J. and Case, V.W, "Sampling, handling and analyzing plant tissue samples", In Soil testing and plant analysis, Westerman RL (ed.), SSSA, Madison, USA, 1990.

[58] Sanchez, P.A., Palm, C.A. and Buol, S.W, "Fertility capability Classification: a tool to assess soil quality in the tropics", Geoderma 114, 157-185, 2003.

[59] Esu, I.E, 1991, "Detailed soil survey of NIHORT farm at Bunkure Kano State, Nigeria", Institute Agric Res, Zaria.

[60] FAO,. - Soil map of the world, REVISED Legend, World Soil Resources Report, FAO, Rome, 1990, 119.

[61] Nwaka, G.I.C, "Studies on dune soils of Borno State". Morphology, classification and physical properties. Annals of Borno, 6: 7, 198 -204, 1990.

[62] Juo, A.S.R. and Moorman, F.R. Characteristics of two soil toposequences in South-eastern Nigeria and their relation to potential agricultural land use. Nigerian Journal of Soil Science 1, 47-61, 1981.

[63] Essoka, P.A., Jaiyeiba, I.A,, and Essoka, A.N, "A Toposequence study of soils developed on gneiss and granodiorite on the Cross River rainforest zone" in Proceedings of the $31^{\text {st }}$ Annual Conference of the Soil Science Society of Nigeria, $13^{\text {th }}-17^{\text {th }}$ November, Soil Science Society of Nigeria, Zaria, Nigeria, 2006.

[64] Idoga, S., Ibanga, I.J., Malgwi, W.B, "Variation in Soil Morphological and physical properties and their management implications on a toposequence in Samaru area", Nigeria, in Proceedings of the 31st annual conference of the soil science society of Nigeria, 13th-17th November 2006, ABU, Zaria, Nigeria, 2006

[65] Duchaufour, P, Abrégé de pédologie, Masson, Paris, France, 1997.

[66] Prusty, B.A.K., Chandra, R., Azeez, P.A, "Distribution of carbon, nitrogen, phosphorus and sulphur in the soil in a multiple habitat system in India", Australian Journal of Soil Research, 47, 177-189, 2009.

[67] Anonymous, "Memento de l'agronome", Collections techniques rurales en Afrique, Paris, France, 1993.

[68] Dabin, B, "General study of soil usage conditions in the Chad Trough", ORSTOM, Paris, France, 1964.

[69] Boyer, J, "Attempted summary of state-of-knowledge on the factors of soil fertility in French intertropical Africa". ORSTOM, Paris, France, 1970.

[70] Martin, D, "Chemical fertility of soils in a ranch in Congo", Cahiers ORSTOM, Sér Pédologie, 17 (1), 47-64, 1979.

[71] Forestier, J, Fertilité des sols des caféières en RCA. Agronome Tropical, 15(5), 543-567, 1960.

[72] MAAF, "Fertilizer recommendation for agriculture and horticulture crops", Ministry of Agriculture, Fisheries and Reference book Series, London, UK, 2000.

[73] Jones, J., Jr, B., Eck, H.V, "Plant analysis as an aid in fertilizing corn and grain sorghum" In Soil Testing and Plant Analysis, Walsh, L.M. and Beaton, J.D, (eds.), 349-364. Soil Sci. Soc. Amer, Madison, USA, 1973.

[74] Harmsen, L. and Vlek, P.L.G. "The chemistry of micronutrients in soils". Fertilizer Research 7: 56-67, 1985.

[75] Pesquini, M.W. "The use of town refuse ash in urban agriculture around Jos, Nigeria: health and environmental risks", Science of the total environment, 354, 43-59, 2006.

[76] Waheed, A., Jaffar, M. and Masud, K, "Comparative study of selected essential and non essential metals in various canned and raw foodstuffs consumed in Pakistan". Nutrition and food Sci, 33(6), 34-41, 2003.

[77] Vitosh, M.L., Warncke, D.D., Lucas, R.E. "Secondary and Micronutrients for vegetables and field crops". Michigan State University, Michigan, USA, 1994.

[78] Dara, S.S, "Environmental chemistry and pollution control". Rajendra Ravindra Printer Ltd, New Delhi, India, 1985.
[79] Landon, J.R, "Booker tropical soil manual: A handbook for soil survey and agriculture evaluation in the tropics and sub-tropics". Longman: Harlow, UK, 1984.

[80] Marschner, H, "Functions of mineral nutrients", In Mineral nutrition of higher plant, Marschner, H, (ed.), Academic Press, New York, USA, 1998.

[81] Ayangnigni, M.F, "Effet de stress hydrique et de la fréquence d'irrigation sur la croissance et le rendement de la morelle noire (Morelle noire)". Mémoire de fin d'étude, FASA, CUDs, Dschang, Cameroun, 2004.

[82] Marschner, H, "Mineral nutrition of higher plants", Academic Press, New York, USA, 1995

[83] Onianwa, P.C., Adeyemo, A.O., Idowu, O.E., Ogabiela, E.E, "Copper and zinc contents of Nigerian foods and estimates of the adult dietary intakes", J Food Chem, 72, 89-95, 2001.

[84] Von Uexküll, HR. and Mutert, E, "Global Extent, Development and Economic Impact of Acid Soils", Plant Soil, 171 (1), 1-15, 1995.

[85] Kabata-Pendias, A, "Trace elements in soils and plants". CRC Press, LLC, 2001

[86] Foy, C.D, "Soil chemical factors limiting plant root growth". In Advances in Soil Sciences: Limitations to Plant Root Growth Hatfield, J.L., Stewart, B.A, (eds.), Springer Verlag, New York, 1992, 97-149

[87] Foy, C.D., Duke, J.A., Devine, T.E, "Tolerance of soybean germplasm to an acid tatum subsoil", J. Plant Nutr, 15, 527-547, 1992.

[88] Foy, C.D, "Physiological effects of hydrogen, aluminum and manganese toxicities in acid soils", In Soil Acidity and Limiting, Adams F (Ed.), Amer Soc Agron, Madison, USA, 1984, 57-97.

[89] Muñoz-Sanchez, A.J., Domínguez-Domínguez, E.R. and Teresa Hernández-Sotomayor, S.M, "Characterizing the relationship between aluminum content and $\mathrm{pH}$ in coffee (Coffea arabica $\mathrm{L}$.) crop soils in Mexico". International Journal of Agriculture and Crop Sciences, 8 (1), 39-46, 2015.

[90] Sauve, S., Hendershot, W., Allen, H.E. "Solid solution partitioning of metals in contaminated soils: Dependence on $\mathrm{pH}$, total metal burden and organic matter", Environmental Science and Technology, 34, 1125-1131, 2000.

[91] FAO/WHO, "Joint FAO/WHO Food Standard Program", Codex Alimentarius Commission, Geneva, Switzerland, 2001.

[92] Stolzfus, R.J, "Iron deficiency: global prevalence and consequences" Food Nutr. Bull, 24(4), 99-103, 2003.

[93] Adjia, R., Fezue, W.M.L., Tchatchueng, J.B., Sorho, S., Ngassoum, M.B, "Heavy metals in five leafy vegetables from urban and periurban sites in Ngaoundéré, Cameroon". Iranica Journal of Energy and Environment, 1(2), 124-131, 2010.

[94] Gorbunov, S.M., Lyapunov Okina, O.I., Frontasyeva, M.V., Gundorina, S.F, "Assessment of human organism's intake of trace elements from stapled foodstuffs in Central Region of Russia". Journal of Environmental Chemistry, 14: 1-16, 2004.

[95] Iyaka, Y.A, "Concentration of $\mathrm{Cu}$ and $\mathrm{Zn}$ in some fruits and vegetables commonly available in North-Central Zone of Nigeria". EJEAFCHE, 6 (6), 2150-2154, 2007.

[96] Salama, A.K., Radwan, M.A, "Heavy metals $(\mathrm{Cd}, \mathrm{Pb})$ and trace elements $(\mathrm{Cu}, \mathrm{Zn})$ contents in some foodstuffs from Egyptian markets". Emir J Agric Sci, 17(1), 34-44, 2005.

[97] Oliveres, M., Pizarro, F., De Pablo, S., Araya, M. and Uauy, R, "Iron, zinc and copper: Contents in common Chilean foods and daily intakes in Santiago, Chile". Nutrition 2, 205-212, 2004.

[98] Murphy, L.S. and Walsh, L.M, "Correction of micronutrient deficiencies with fertilizers", in Micronutrients in Agriculture, Mortvedt, J.J, (ed.), Soil Sci. Soc. Am, Madison, USA, 1972, 347387.

[99] Amundson, R., Richter, D.D., Humphrey, G.S., Jobbagy, E.G. and Gaillardet, J. "Coupling between biota and earth material in the critical zone", Elements, 3,327-332, 2007.

[100] Adriano, D.C, "Trace elements in the terrestrial environment". Springer-Verlag, New York, 2001.

[101] ATSDR, "Minimum risk levels (MRLs) for hazardous substances", Agency for Toxic Substances and Disease Registry, [E-book] Http://www.atsdr.cdc.gov/mrls.html. 